\title{
Folk use of medicinal plants in Karst and Gorjanci, Slovenia
}

\author{
Mateja Lumpert ${ }^{*}$ and Samo Kreft
}

\begin{abstract}
Background: Information on the use of medicinal plants in Karst and Gorjanci is not available in the literature, but collection of plants is still an important and widespread practice in these regions. Karst and Gorjanci are two remote regions in Slovenia that are only $120 \mathrm{~km}$ apart but have different climates; one region is close to the Italian border, and the other is near the Croatian border. Our aim was to report and compare the use of medicinal plants in both regions.

Methods: From October 2013 to September 2014, 25 informants each in Karst and Gorjanci were interviewed during field research. The age of the informants ranged from 33 to 89 years, with an average age of 61 years in Karst and 69 years in Gorjanci. The main question was "Which plants do or did you collect from nature and use?" Plants of medicinal, nutritive, veterinary or cosmetic use were considered.

Results: A total of 78 and 82 taxa were reported in Karst and Gorjanci, respectively; 65 taxa were reported in both regions. Approximately $64 \%$ of the plants in each region were distinctive for only a few informants (fewer than 7). The remaining plants were considered important, and the majority were mutual to both regions. Few reported plants were typical for just one region. Differences in the use of some common medicinal plants were observed, e. g., Matricaria chamomilla was used mostly for the treatment of gastrointestinal disorders, respiratory infections and sore eyes in Gorjanci but as a calmative in Karst. Altogether, 15 different oral and 15 different topical medicinal preparations were reported. Folk knowledge was found to be influenced by the media, particularly popular books about medicinal plants that were published in the 20th century.
\end{abstract}

Conclusions: The present research documents the folk use of medicinal plants in Karst and Gorjanci, Slovenia. This rapidly changing practice needs to be documented before it disappears or changes.

Keywords: Ethnomedicine, Folk knowledge, Ethnobotany, Balkan, Comparison, Herbal preparations

\section{Background}

In Slovenia, knowledge about plants is transmitted from generation to generation and is also influenced by written sources. The beginning of this practice goes back to Comments of Dioscorides written by Pietro Andrea Mattioli. He lived and worked from 1540 to 1554 in Gorica, a town in northeastern Italy populated by a Slovene-speaking minority, and he was the first to describe plants of Slovenian flora $[1,2]$. In the 18th and 19th centuries, folk healers in Slovenian ethnic territory used folk medicine manuscripts, which were translations of mostly German medicine and veterinary books, especially herbals (or Kräuterbücher)

* Correspondence: mateja.lumpert@ffa.uni-lj.si

Faculty of Pharmacy, University of Ljubljana, Aškerčeva cesta 7, SI-1000 Ljubljana, Slovenia from the 16th century and the beginning of the 17th century $[1,3]$ Most manuscripts were translations of Gart der Gesundheit (1485), Kreutterbuch by Pietro Andrea Mattioli (1590), Neu Vollkommenes Kräuter-Buch by Pietro Andrea Mattioli (1678), Vollständiges Kräuterbuch by Adam Lonicer (1557), and Neu Vollkomentlich Kreuterbuch by Jakob Tabernaemontanus (1613). Later, the translated books were manually transcribed many times, and the transcribers added their own observations to the manuscripts [1]. In the second half of the 19th century, the first original (non-translated) Slovenian works about medicinal plants were published $[4,5]$, and manuals for the wild collection, drying and use of Slovenian medicinal plants were issued later [6-9]. Throughout the 20th century, there was steady growth of published books about 
medicinal plants; some of them were original Slovenian works, and some were translations from foreign authors; most were written by pharmacists and only some by folk healers [10-27].

The use of plants has been scarcely investigated in Slovenia, and only a few ethnobotanical studies have been conducted. The Karst region is a limestone plateau in southwestern Slovenia that continues on the Italian side of the border [28]. The Italian part of the Karst region, also known as Trieste Karst, was included in an ethnobotanical study of the Venezia Giulia region in 1988, and a list of 59 plants that were used in Trieste Karst was reported [29]. Guštin Grilanc investigated the folk herbalist tradition in both the Italian and Slovenian parts of the Karst region and published a list of 124 plants used for healing, food, toys, superstitions, and folk traditions with short descriptions [30]; however, the methodology of the work was not described, and only a detailed list of informants was given. Gorjanci is a mountain range in southeastern Slovenia that runs southwest to northeast along the Croatian border [31]. From 1950 to 1983, ethnographic researchers collected testimonials on the natural and magical treatment of the people in Dolenjska and Bela Krajina, two regions where Gorjanci is located. Makarovič [32] analyzed the collected testimonials and concluded that the ethnographers' notes contained random and generalized data on knowledge about natural medicines and magical practices; those data were collected unsystematically and were incomplete. As a result, this analysis provided a very rough estimation of the use of medicinal plants. A total of 112 plants were mentioned (botanical names were often missing, and only the local names were given), and the most frequent were Matricaria chamomilla, Sambucus nigra, Allium sativum, Juniperus communis, Tilia platyphyllos, Allium cepa, and Sempervivum tectorum.

In addition, some socio-economic studies [33-35] investigated the plants people use in Slovenia. According to these studies, the most frequently used plants in Slovenia were Achillea millefolium, Hypericum perforatum, Matricaria chamomilla, Mentha piperita, Salvia officinalis, Sambucus nigra, Tilia platyphyllos, and Urtica dioica (Table 1). A survey on wild-growing edible plants and human nutrition was conducted using a Slovenian cookbook and informants from different regions of Slovenia. According to the informants, the five most frequently reported taxa were Taraxacum officinale agg., Fragaria sp., Castanea sativa, Vaccinium myrtillus and Sambucus nigra; according to the cookbooks, the five most frequently mentioned taxa were Juglans regia, Armoracia rusticana, Castanea sativa, Corylus avellana, and Taraxacum officinale agg. [36].

Similar to the neighboring countries of Austria [37, 38] and Italy [39-42], the wild collection of plants is also important in Slovenia. According to a survey conducted in seven pharmacies [34], the informants obtained medicinal plants from a pharmacy $(68 \%)$ or by wild collection (48\%). Other possible sources were friends and relatives (33\%), specialized shops (19\%), and herbalists (17\%). In another study conducted in the city of Velenje, the informants obtained medicinal plants by wild collection (37\%), from relatives (25\%), from a pharmacy $(24 \%)$ or from a market (5\%) [35].

Limited information about the folk use of plants for medicinal and nutritive purposes is available for Slovenia. This paper reports the results of a study on the use of plants in two areas in Slovenia: Gorjanci in southeastern Slovenia and Karst in western Slovenia. The areas are approximately $120 \mathrm{~km}$ apart; one is close to the Italian border, and the other is close to the Croatian border. Except for one mountain pass, Gorjanci is rather impassable to Croatia, whereas Karst is more passable to Italy and is the hinterland of Trieste, which has been a trading port for centuries. Karst is a transitional region with Mediterranean and continental influences, and Gorjanci has a moderate continental climate. Both areas are rural and remote, and the landscape is only partially cultivated. They are inhabited by a Slovene population (approximately $95 \%$ ). In the past, the inhabitants were farmers, but the active population currently consists of daily migrants to industrial centers. People are still connected to nature, and knowledge about plants is important in their lives because they produce their own food in gardens or fields and some are still farmers $[28,31]$. This study focused on plants for medicinal use but also includes plants for nutritive, cosmetic and veterinary uses. This study aimed to investigate the following: 1) the plants used in villages in the foothills of Gorjanci and in Karst, 2) the plant preparations and purposes for their use, and 3) the differences in the use of plants between Gorjanci and Karst; these could be the result of differences in climate, vegetation or connections to neighboring areas.

\section{Methods}

\section{Research area}

The use of plants was investigated through interviews with local people in villages in the Karst plateau in southwestern Slovenia and in villages in the foothills of the Gorjanci mountain range in southeastern Slovenia (Fig. 1). The interviews were conducted from October to December 2013 and from May to September 2014. The villages in Karst included Pliskovica, Veliki dol, Brje pri Komnu, Gorjansko, Klanec pri Komnu, Štanjel, Kobdilj, Grahovo Brdo, Griže and Štjak (altitudes ranging from 184 to $518 \mathrm{~m}$ above sea level). The villages in Gorjanci included Iglenik, Vrhe, Dolž, Mali Cerovec, Pangrč Grm, Sela pri Zajčjem Vrhu, Stopiče, Dolenji Suhadol, Cerov 
Table 1 Most frequently used plants in Slovenia, as reported in previous socio-economic studies [33-35]

\begin{tabular}{|c|c|c|c|c|}
\hline \multirow{2}{*}{ Plant species } & \multicolumn{4}{|l|}{ References } \\
\hline & $\begin{array}{l}\text { Plants for } \\
\text { infusions [9] }\end{array}$ & $\begin{array}{l}\text { Plants in herbal } \\
\text { medicinal products [9] }\end{array}$ & $\begin{array}{l}\text { Plants and plant } \\
\text { preparations [10] }\end{array}$ & $\begin{array}{l}\text { Plants for abdominal pain, } \\
\text { headache, diarrhea, and fever [11] }\end{array}$ \\
\hline Achillea millefolium & $x$ & $x$ & $x$ & $x$ \\
\hline Arctostaphylos uva-ursi & $x$ & & & \\
\hline Arnica montana & & & $x$ & \\
\hline Calendula officinalis & & $x$ & & \\
\hline Centaurium minus & & & & $x$ \\
\hline Echinacea purpurea & & $x$ & & \\
\hline Hypericum perforatum & & $x$ & $x$ & $x$ \\
\hline Matricaria chamomilla & $x$ & & $x$ & $x$ \\
\hline Mentha piperita & $x$ & & $x$ & $x$ \\
\hline Rosa canina & & & & $x$ \\
\hline Salvia officinalis & $x$ & $x$ & $x$ & $x$ \\
\hline Sambucus nigra & $x$ & $x$ & $x$ & $x$ \\
\hline Tilia platyphyllos & $x$ & $x$ & $x$ & $x$ \\
\hline Urtica dioica & $x$ & $x$ & $x$ & \\
\hline Vaccinium myrtillus & & & & $x$ \\
\hline Valeriana officinalis & & $x$ & & \\
\hline
\end{tabular}

Log and Mihovo (altitudes ranging from 232 to $442 \mathrm{~m}$ above sea level).

Karst is a limestone plateau in southwestern Slovenia. The climate has Mediterranean and continental influences [28], and the mean precipitation ranges from 1400 to $1650 \mathrm{~mm}$ per year [43]. The mean January and July temperatures are 2.4 and $20.8{ }^{\circ} \mathrm{C}$, respectively. The predominant bedrock is limestone, which is vulnerable to corrosion. The bedrock is covered with chromic cambisol, chromic luvisol and rendzina. The natural forests are composed of pubescent oak (Quercus pubescens), hop hornbeam (Ostrya carpinifolia) and flowering ash (Fraxinus ornus) [44]. In the 19th century, parts of Karst were afforested with black pine (Pinus nigra). The population density is 41 people per $\mathrm{km}^{2}$, and the farming population represented $4.1 \%$ of the total population in

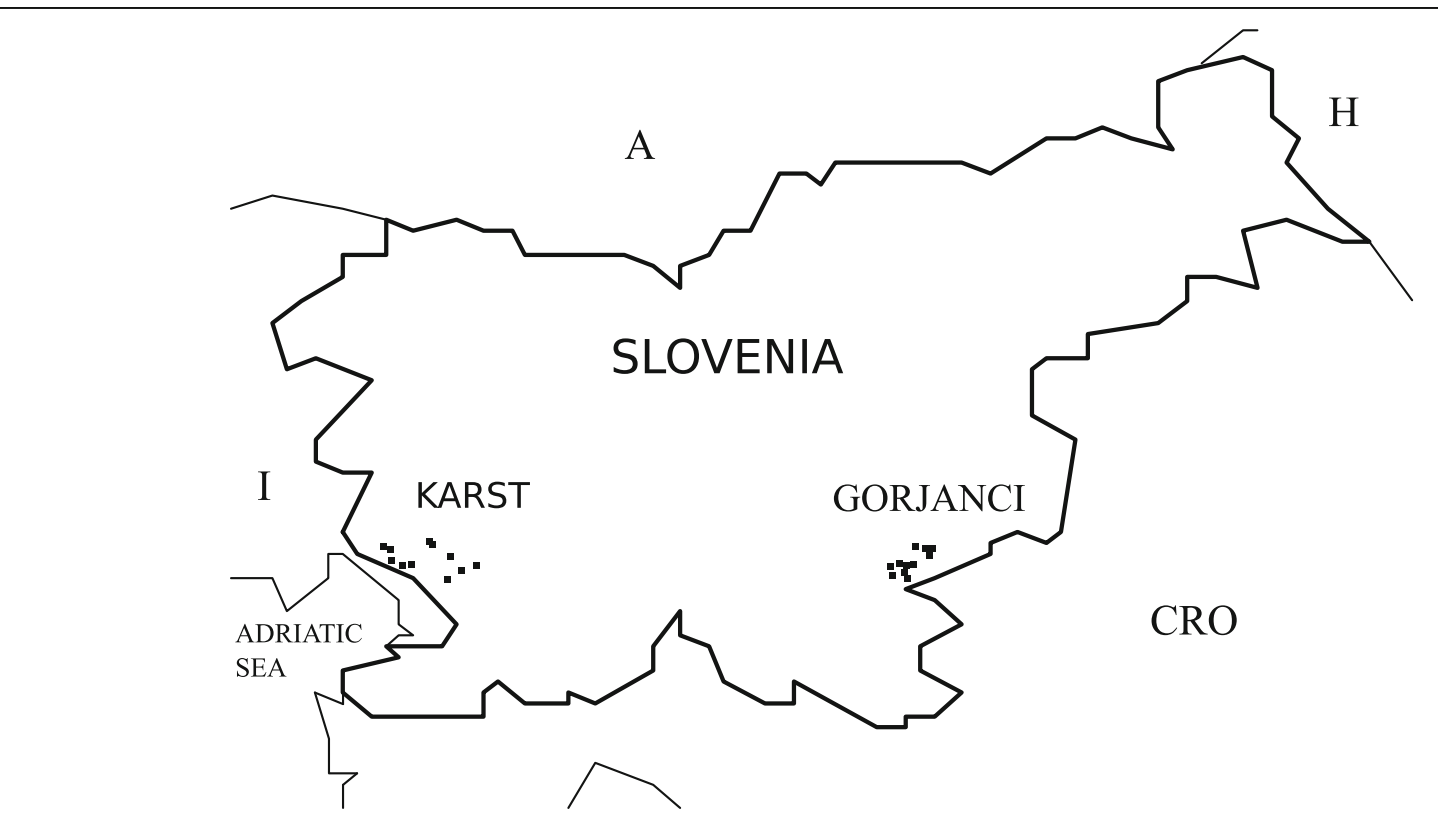

Fig. 1 Map of the study area. The villages where the interviews were conducted are represented by dots 
1991. There are 100 settlements [28]. Industrialization with employment began after the Second World War and advanced after 1960. The active population began to travel daily from rural areas to the surrounding industrial centers [45].

Gorjanci is a mountain range in southeastern Slovenia. It has a moderate continental climate with mean precipitation between 1100 and $1300 \mathrm{~mm}$ per year. In the foothills, the mean January and July temperatures are approximately 0 and $20{ }^{\circ} \mathrm{C}$, respectively. Gorjanci consists primarily of limestone and dolomite and is covered with rendzina and chromic cambisol. The higher regions of Gorjanci are overgrown with extensive beech forests (Fagus sylvatica). Some areas have been deforested for pasture and are now becoming naturally overgrown or reforested with spruce (Picea abies) and fir (Abies alba). Forests of beech (Fagus sylvatica) and hop hornbeam (Ostrya carpinifolia) grow in the eastern part of Gorjanci. Oak (Quercus petraea) forests grow in the western and central parts of Gorjanci up to 400 and $600 \mathrm{~m}$ in altitude, respectively. The area is sparsely populated; the population density was 27 people per $\mathrm{km}^{2}$ in 1991. The highest number of inhabitants, 8000, occurred at the beginning of World War II. This remote area is characterized by the depopulation of young people, who migrate to cities. There are 87 settlements, most of which are located on the periphery. In 1961, two-thirds of the population were farmers, whereas $22.2 \%$ of the population was farmers in 1991. Farmers produce livestock and mostly grow fodder plants [31].

\section{Data collection}

In the study, 25 informants each were interviewed in Karst and in Gorjanci. The age of the informants ranged from 33 to 89 years, with an arithmetic mean age of 61 years in Karst and 69 years in Gorjanci (Table 2). In Karst, 23 informants were originally from the Karst region, and two informants were born near that region. In Gorjanci, 17 informants were originally from villages in the foothills of Gorjanci, and 8 informants were born close to that region (30 km radius). Purposive and snowball sampling methods were used in this study [46, 47]. Informants were contacted in villages (on the street, outside their house or in the field). They were often recommended by other members of their family as being more knowledgeable and by other informants in their village or neighboring villages. The informants were recruited without any selection based on sex, age or social status.

Table 2 Informants' age and sex in Karst and Gorjanci

\begin{tabular}{|c|c|c|c|c|c|c|}
\hline & \multirow{2}{*}{$\begin{array}{l}\text { Average } \\
\text { age (years) }\end{array}$} & \multicolumn{3}{|c|}{ Age (years) } & \multicolumn{2}{|l|}{ Sex } \\
\hline & & $33-49$ & $50-69$ & $70-89$ & Male & Female \\
\hline Karst & 61 & 4 & 15 & 6 & 6 & 19 \\
\hline Gorjanci & 69 & 5 & 4 & 16 & 1 & 24 \\
\hline
\end{tabular}

The interviews were performed in the homes of the informants and in the fields. The language used in the interviews was Slovenian. The informants were made aware of the scope of the study, and informed consent was obtained.

\section{Interviews and statistical analysis}

Free-listing and semi-structured interviews were used to collect data $[47,48]$. At the beginning of the interview, the informants were asked to list the plants that they use currently or used in the past and that are collected from nature. They were asked the following free-listing question: "Which plants do or did you collect from nature and use?" Then, they were asked the following questions for each plant:

- Which part of the plant do you use?

- How do you prepare it?

- What is it good for?

- Who would you recommend it to?

At the end of the interview, the informants were also asked to answer the following questions about the sources of their knowledge:

- "Where did you get your knowledge about plants?" and "Did anybody show or tell you something about plants?"

The informants' answers were written in a notebook and then entered and organized in worksheets in Microsoft Excel 2010 [49]. Statistical analyses were performed using MS Excel, Visual Anthropac [50], and SPSS [51]. Visual Anthropac was used to perform an analysis of the free-list data in which frequency, rank, and Smith's salience index were calculated. Rank (order) and frequency of mention are two measures of importance (salience) that are combined into a single index called the Smith's salience index [52]. Other statistical analyses were performed using MS Excel and SPSS. SPSS was used to perform Pearson's chi-squared test and Fisher's exact test. Since purposive sampling was used for informant selection, the results of the statistical analysis are limited to the population under study [46].

\section{Plant material}

Plant samples (fresh plants, dried plants and sometimes herbal preparations) were collected at informants' homes or nearby when possible (sometimes this was not possible due to the condition of the informant's health or the weather). When possible, more knowledgeable informants were followed into the field to show us the reported plants. The plants were identified by both authors and stored at the herbarium of the Faculty of 
Pharmacy, University of Ljubljana. Cultivated plants were not collected. The plant nomenclature followed Mala flora Slovenije [53] and was checked using the online database The Plant List ( http://www.theplantlist.org/). In some cases, which are reported in the results section, the informants used several species belonging to the same genus for the same purposes, although they were aware that they were different species (Artemisia spp., Mentha spp., Plantago spp., Quercus spp., and Trifolium spp.). Furthermore, in some cases, the informants did not distinguish among different species belonging to the same genus (Asparagus spp., Crataegus spp., Centaurium spp., Lavandula spp., Rosa spp., Rubus spp., Solidago spp., and Tilia spp.).

\section{Results and discussion}

General data on the plants reported in Karst and Gorjanci In each region, 25 informants were interviewed and reported a total of 94 plants, including 77 in Karst and 81 in Gorjanci; 64 plants were reported in both regions (Table 3).

On average, the informants reported 20 different plants per interview in both regions (Karst: standard deviation 5.9, max. 30, min. 9; Gorjanci: standard deviation 10.4, max. 42, min. 6). Altogether, the informants made 493 reports of collected plants in Karst and 490 in Gorjanci. The informants in both regions reported 47 wild plants, 12 plants that grow wild and can be cultivated and 35 cultivated plants, although they were asked to list the plants that they collected in the wild. Listing of cultivated plants instead of plants collected in the wild has also been observed in other studies [38, 54]; it is likely that informants mentally link the reported wildcollected plants to homemade remedies and then remember other plants that are also used for home remedies, although they are cultivated. It is also possible that they cultivate some plants that are primarily found in the wild [38].

The important plants in each region (Table 4) were mentioned frequently and were mentioned early in the interview (low rank); the frequency and rank were significantly correlated in both Gorjanci and Karst (Pearson's correlation $p=0.0007$ and $p<0.00001$, respectively). The important plants had also a high Smith's salience index, which quantifies the importance of a plant in relation to its frequency and order of mention (rank) in free-listing [52]. Many plants were distinctive for one or a few informants. In each region, approximately $64 \%$ of the plants were mentioned by fewer than 7 informants, and approximately $36 \%$ of the plants were mentioned by at least 7 informants. The informants mentioned 49 plants in Karst and 52 in Gorjanci that had a frequency of 1 to 6; in addition, they mentioned 28 plants in Karst and 29 in Gorjanci that had a frequency of 7 to 24 (Table 3). The above-mentioned results show that some plants were mentioned very frequently, and many plants were mentioned by a few informants. The frequency of mention decreased gradually, and there was no noticeable break in the frequency of mention between plants mentioned by many informants and plants mentioned by just a few informants; therefore, a small group of important plants for each region could not be obtained [48].

The most frequently reported plant was Sambucus nigra; 24 informants in Karst and 24 informants in Gorjanci (K: 24; G: 24) reported use of this plant. $S$. nigra has also been frequently reported in northern Italy [55] and in some parts of Austria [37, 56], Croatia $[57,58]$ and Bosnia and Herzegovina [59]. Other frequently reported plants were Rosa spp., Salvia officinalis, Thymus serpyllum, Mentha spp., Melissa officinalis, Matricaria chamomilla, and Tilia spp. in Karst and Achillea millefolium, Tilia spp., Matricaria chamomilla, Urtica dioica, Hypericum perforatum, Rosa spp., Centaurium spp., and Vaccinium myrtillus in Gorjanci. The above-mentioned plants were reported by at least 15 informants in one region (Table 4). These plants belong to the European ethnomedicinal flora; some of them (e.g., Sambucus nigra and Urtica dioica) are common and abundant wild species with a wide distribution area and frequent use, while others are widely used cultivated plants, e.g., Matricaria recutita and Tilia spp. [60].

In a comparison of plants reported in Slovenia and those reported in ethnobotanical studies in Austria, Serbia and Bosnia and Herzegovina, many similarities were observed. Many plants reported in our study were also reported in Austria: 22 out of 27 wild-collected food plants in a hilly area in Styria [61], 48 out of 76 wild or cultivated plants reported in the Alpine valley Grosses Walsertal [37], and 28 out of 64 wild-collected plants in Kartitsch (eastern Tyrol) [54]). Approximately half of the listed plants in Serbia were also reported in Slovenia: 46 out of 69 in southwestern Serbia [62], 23 out of 45 in Mt. Rtanj (eastern Serbia) [63], 60 out of 128 on Suva Planina mountain (southeastern Serbia) [64], and 38 out of 83 on Kopaonik Mountain (central Serbia) [65]. Similar use of plants was also observed in Bosnia and Herzegovina: 76 out of 254 wild and cultivated medicinal plants in eastern, northern and northeastern Bosnia and Herzegovina [59]; and 73 out of 228 wild and cultivated medicinal plants in central, southern and western Bosnia and Herzegovina [66]. We did not observe any important plants used in any of the two studied areas that had not been previously reported in the above-mentioned neighboring areas.

While the focus of our study was the medicinal use of plants, the informants did not make a clear distinction between medicinal and nutritive uses and reported a broad spectrum of uses. We classified these uses into 


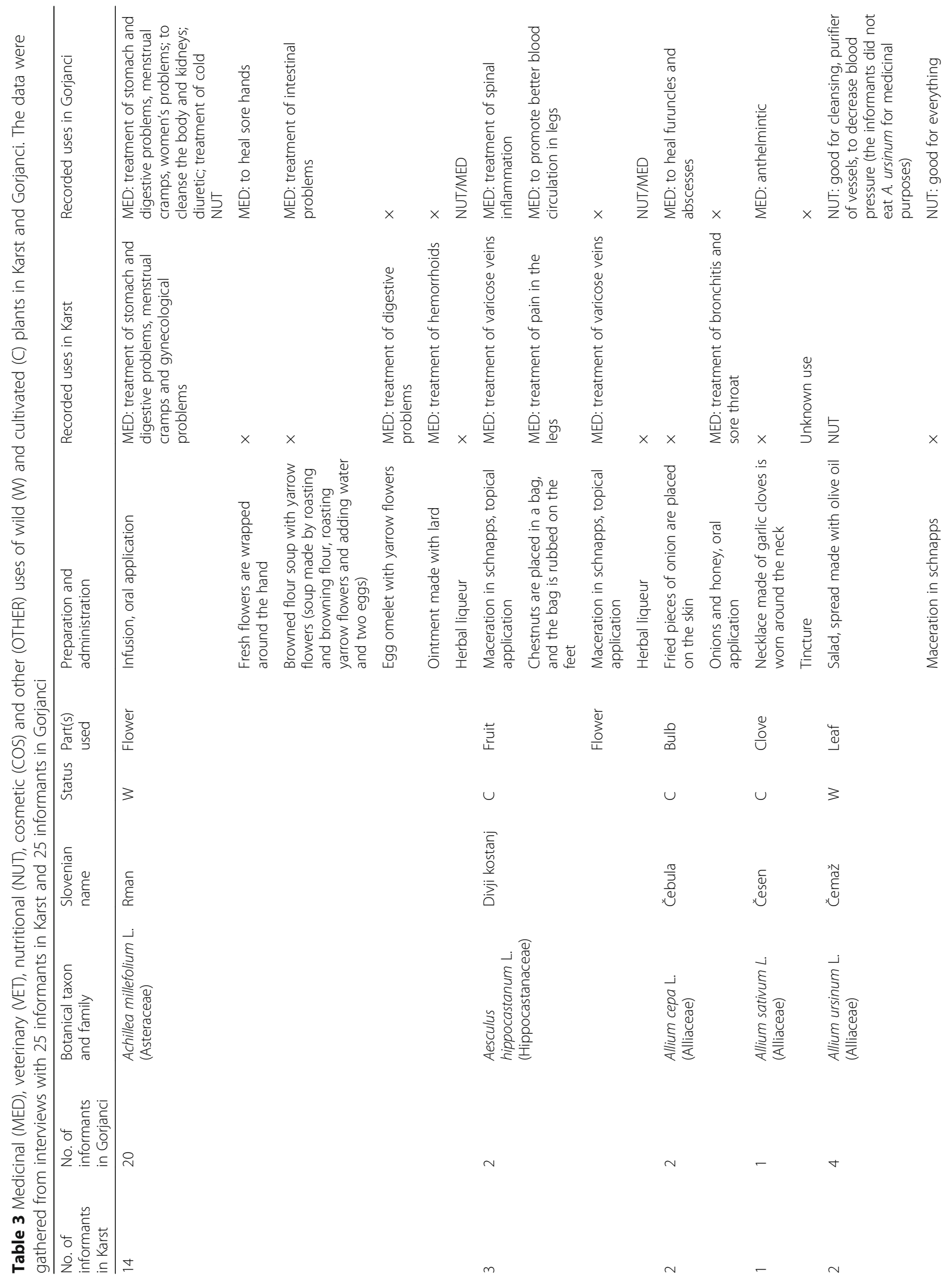




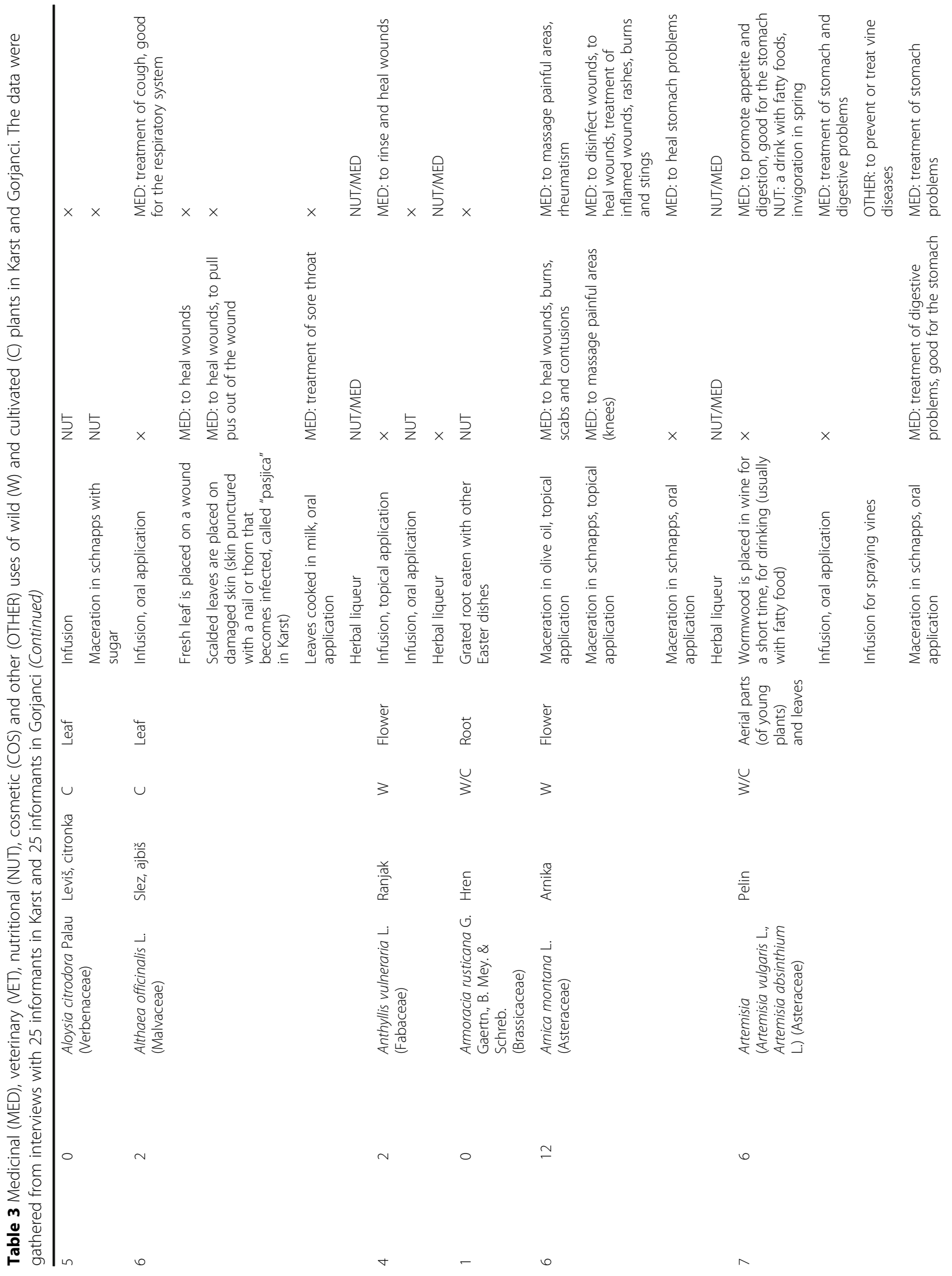




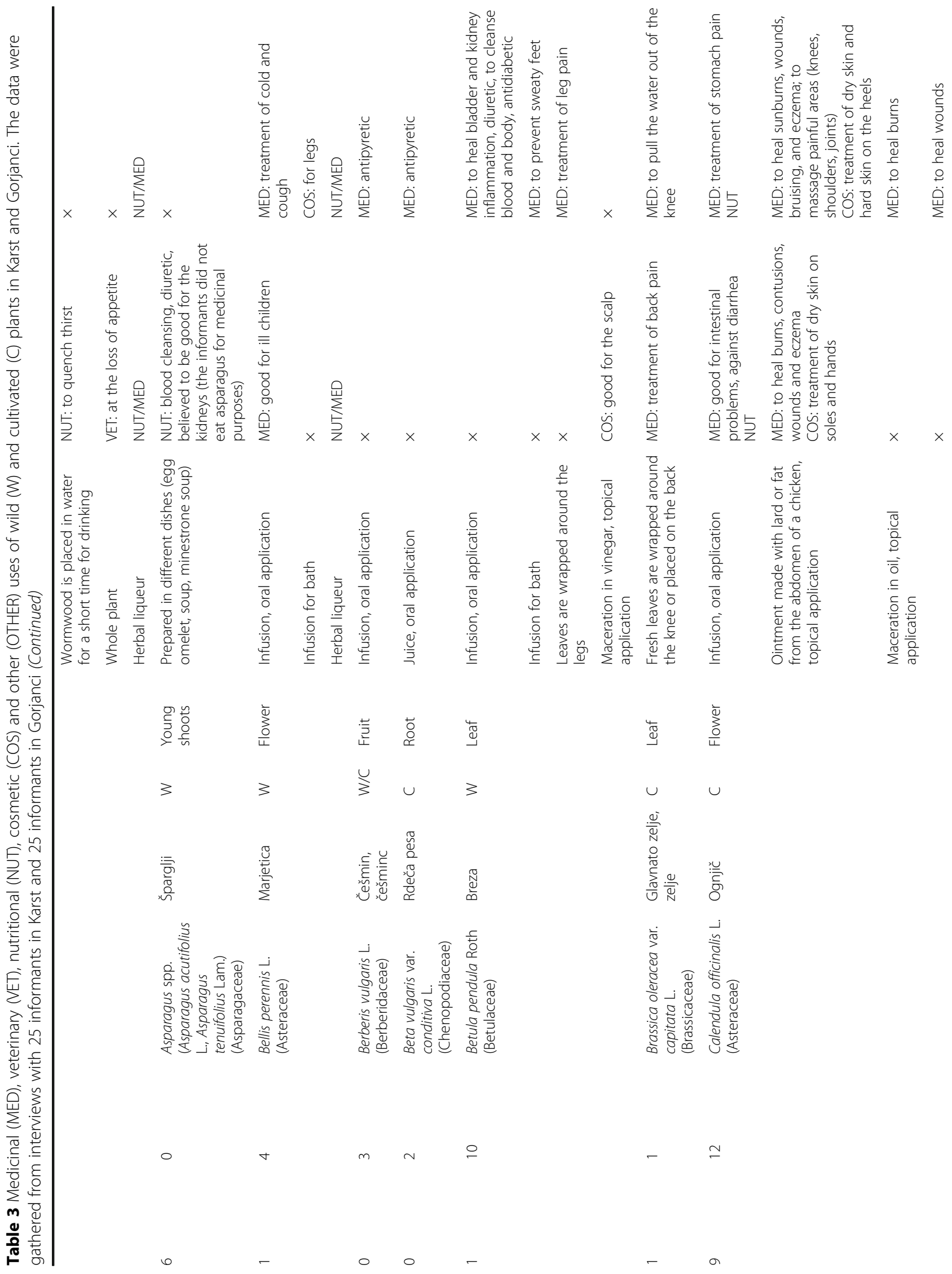




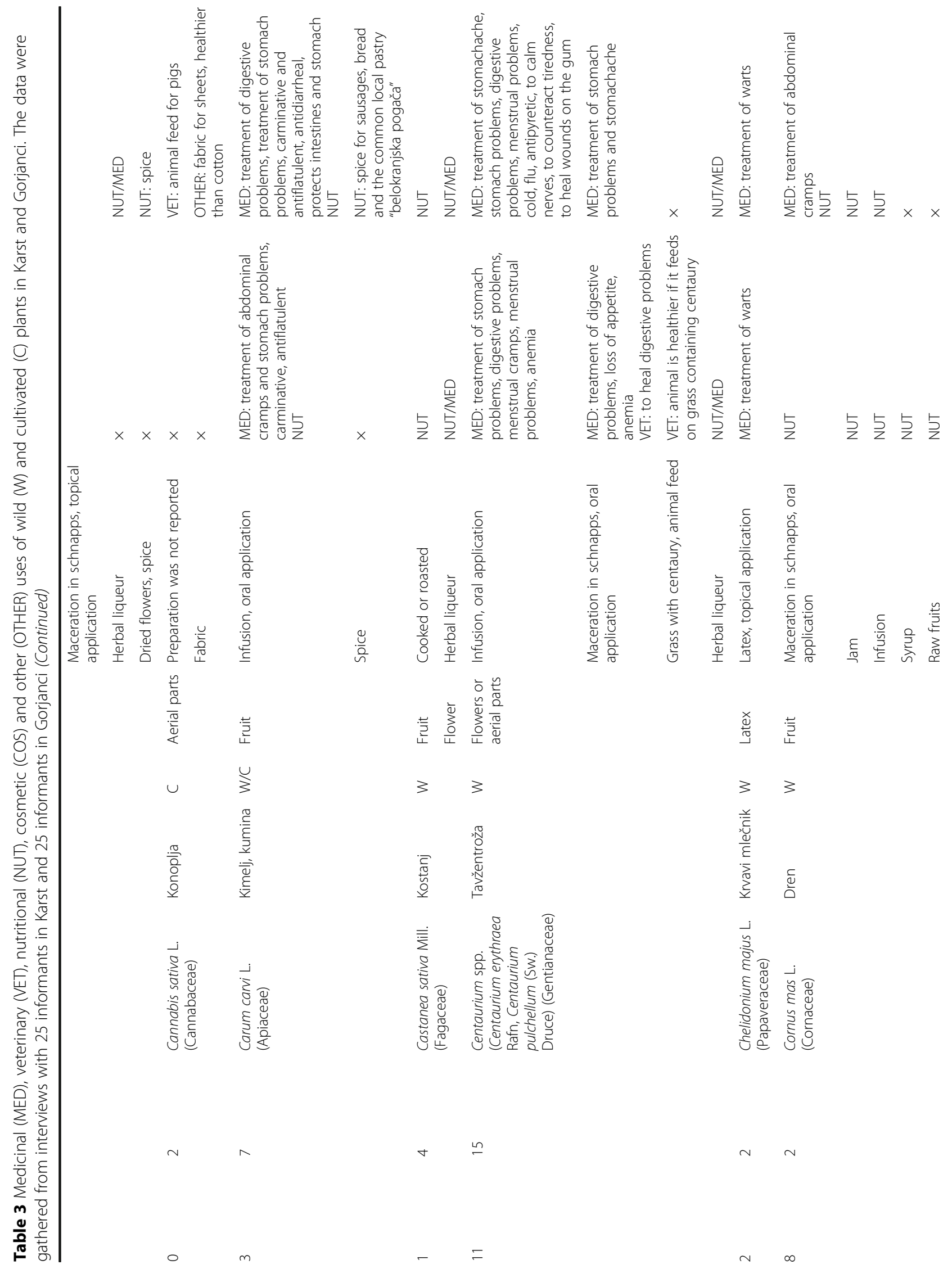




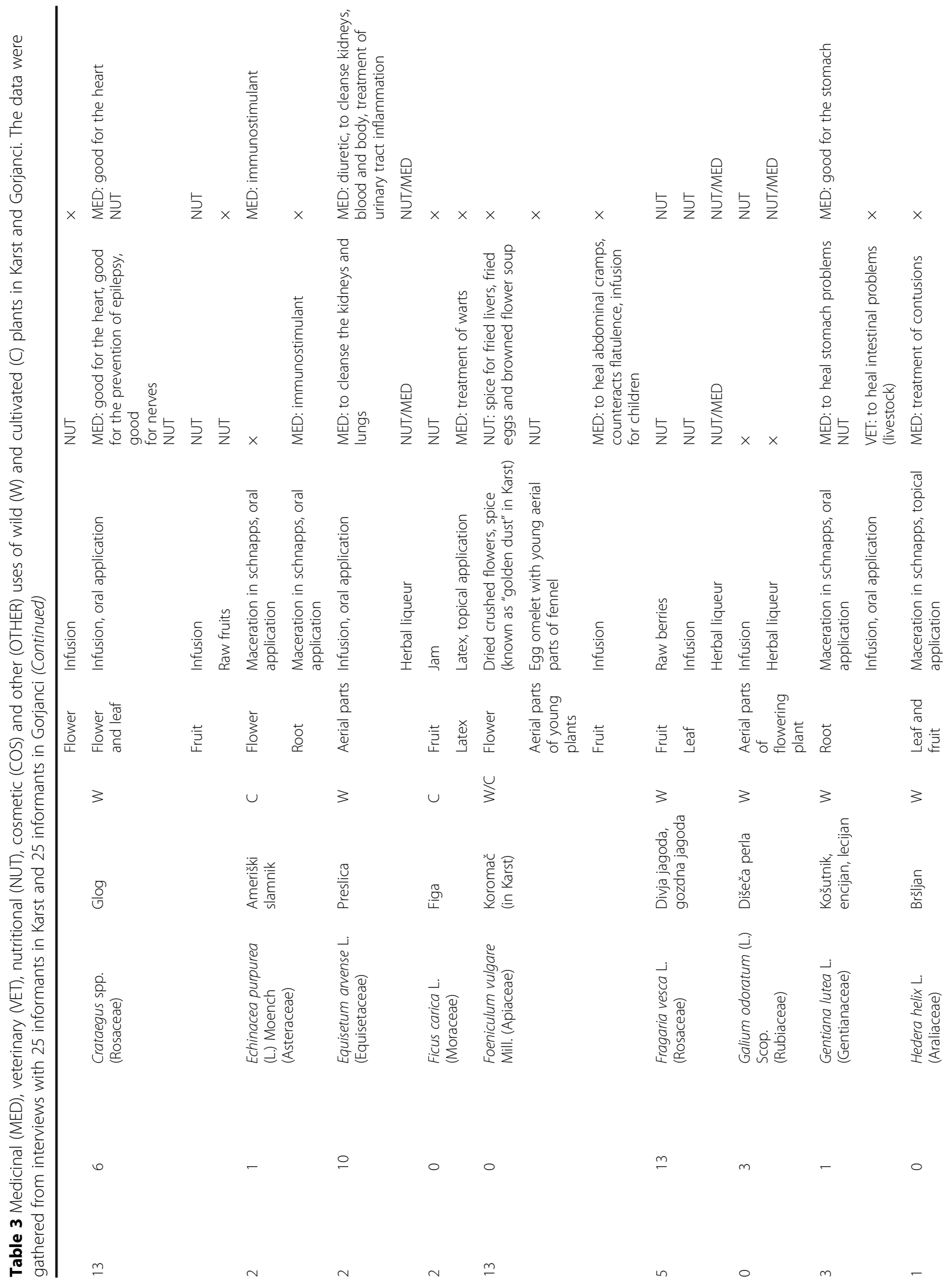




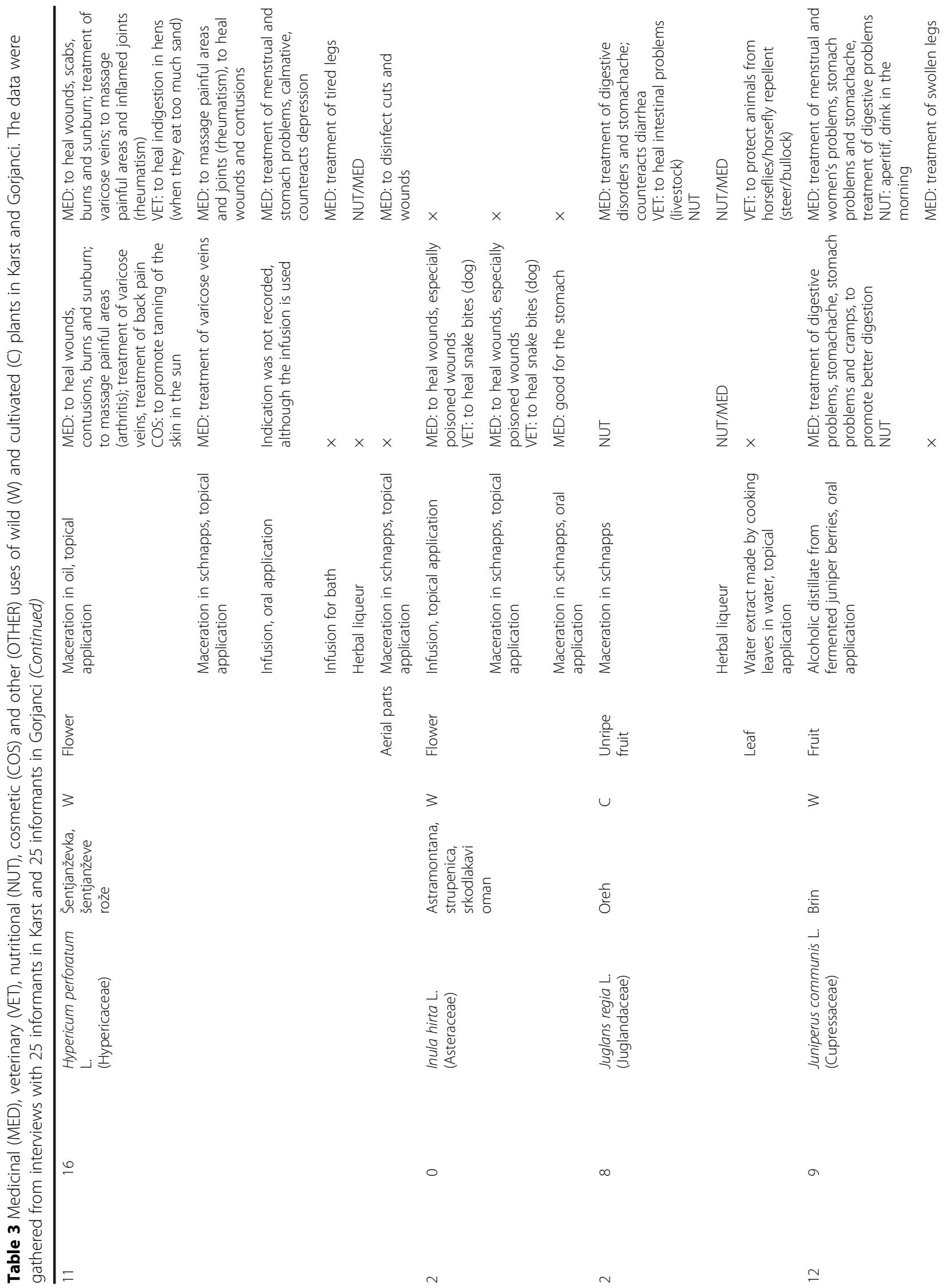




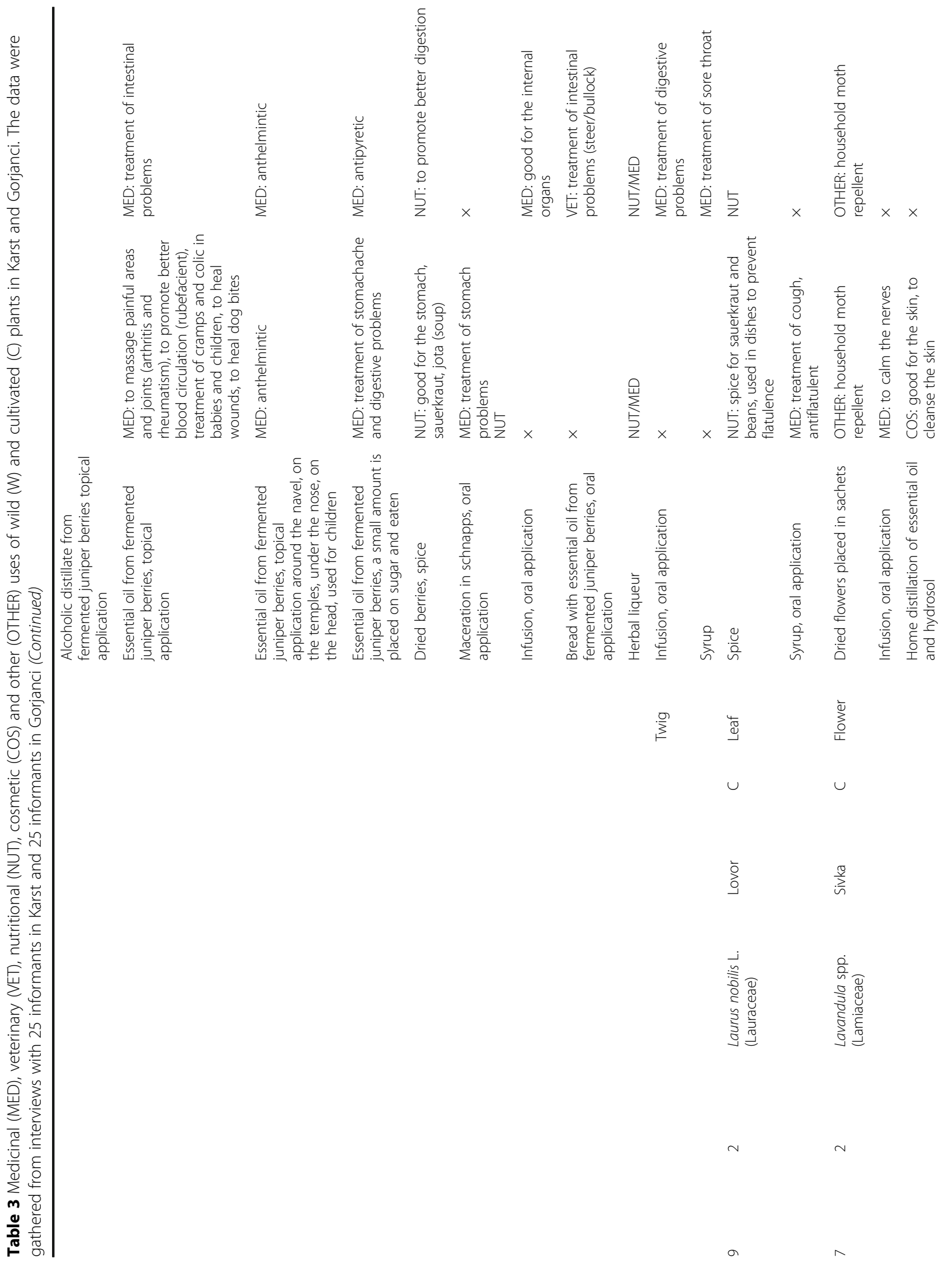




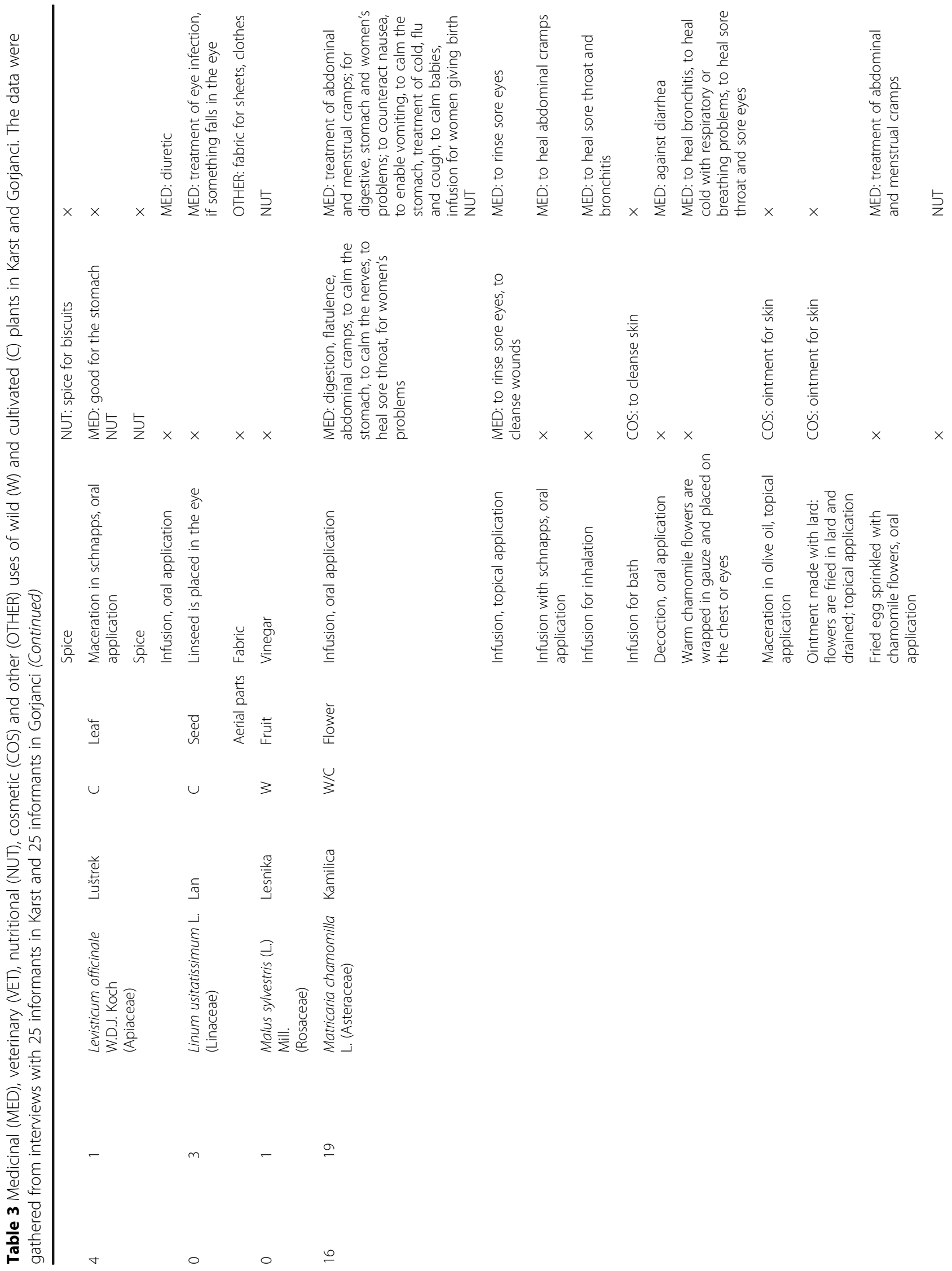




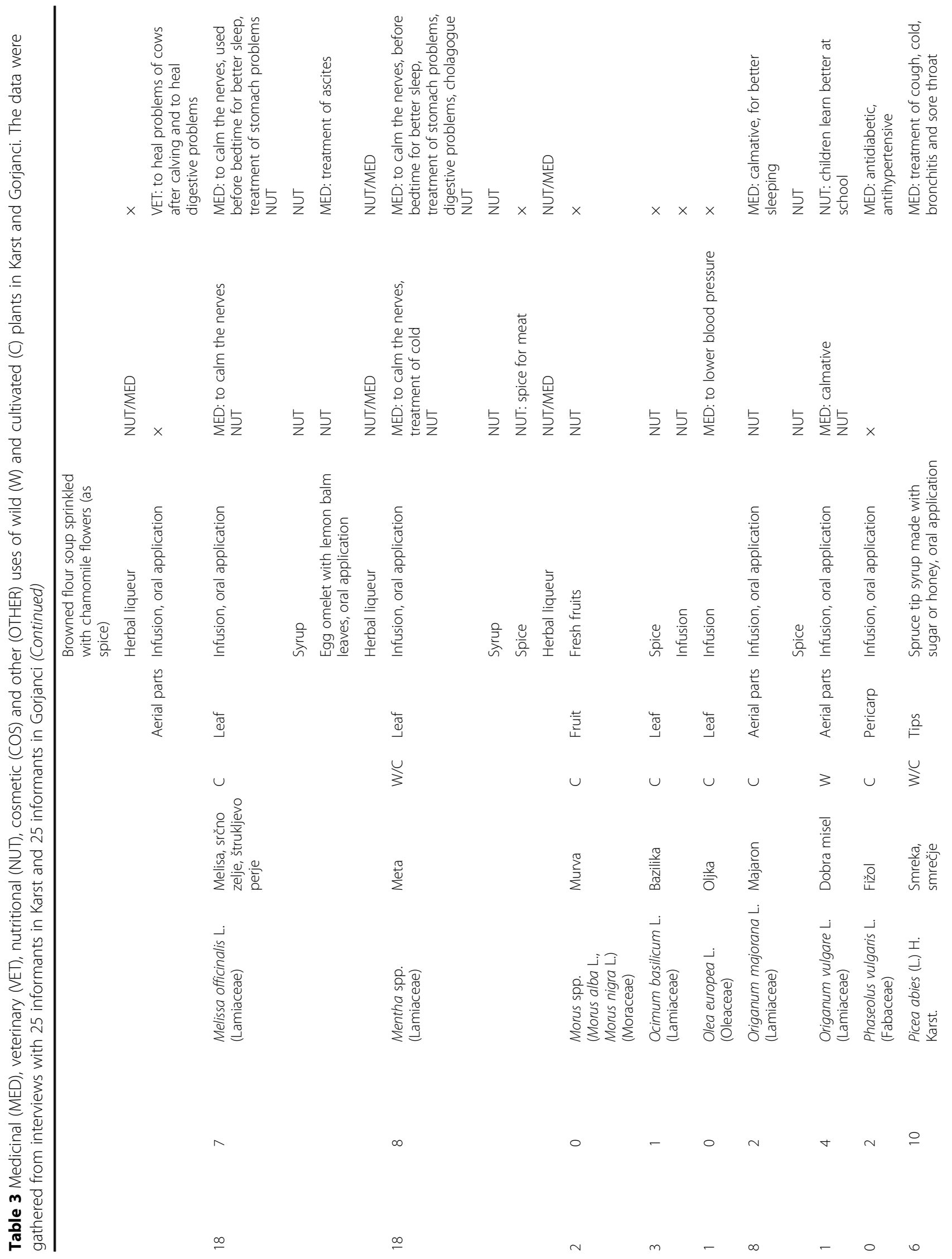




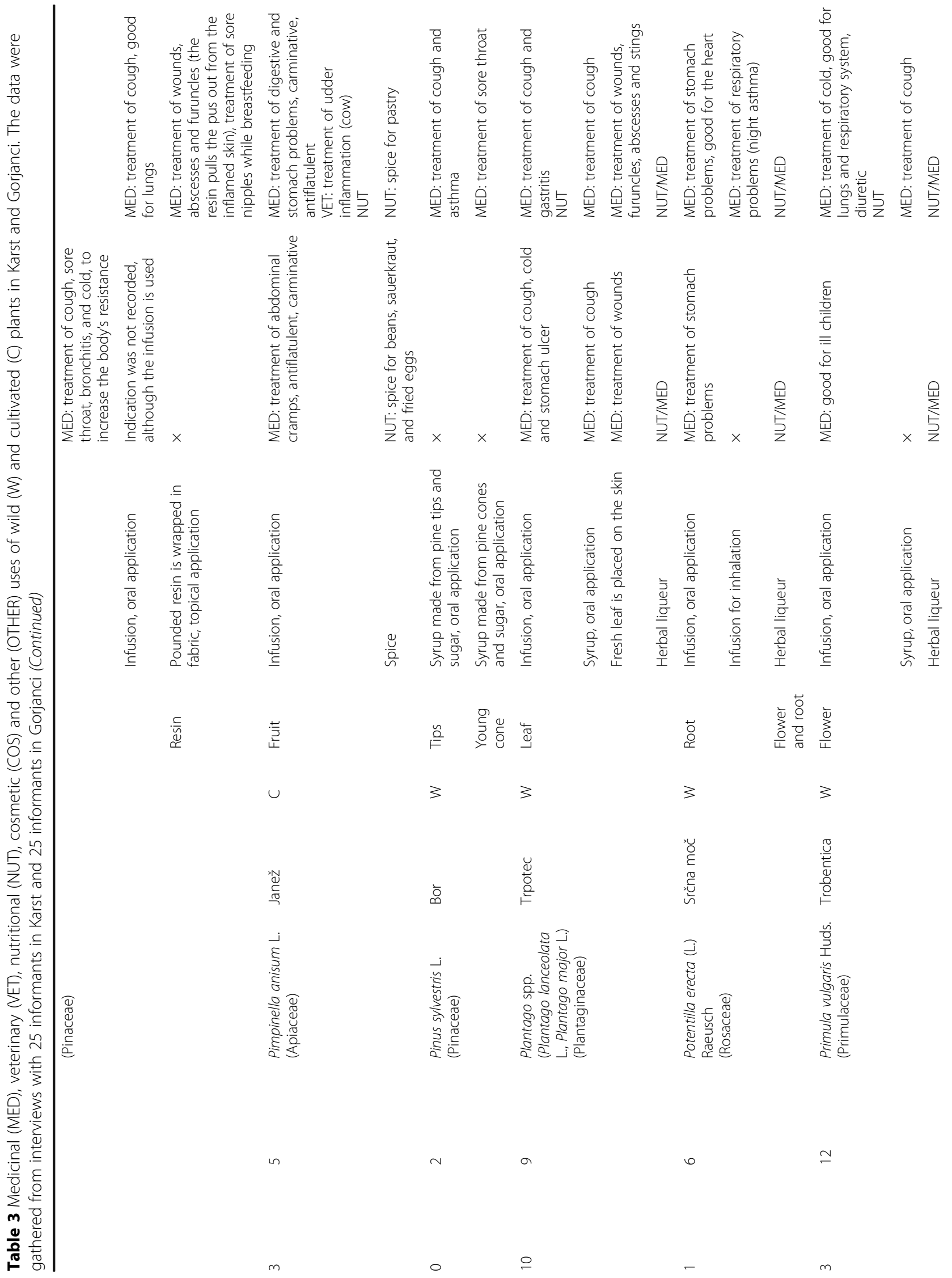




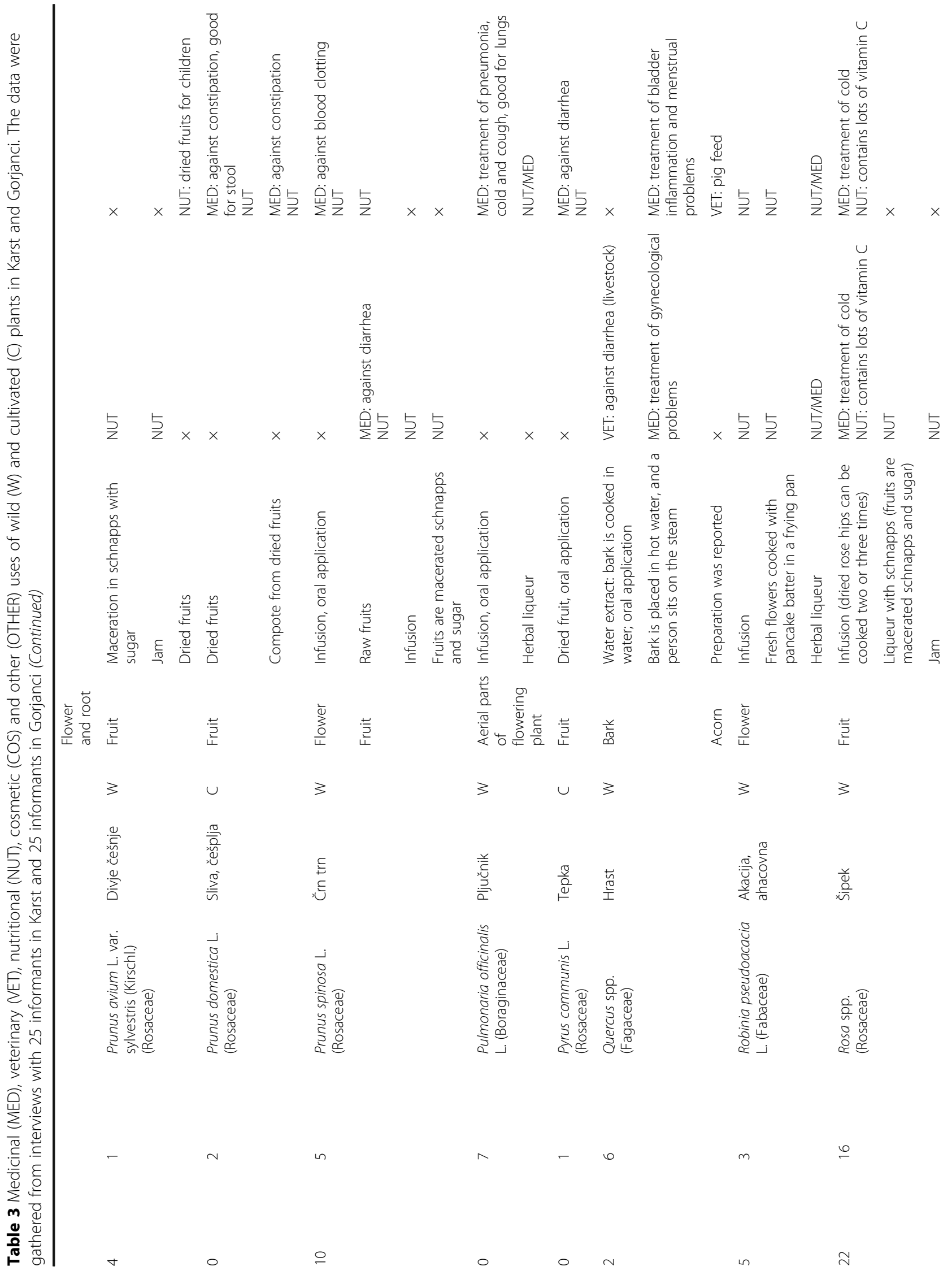




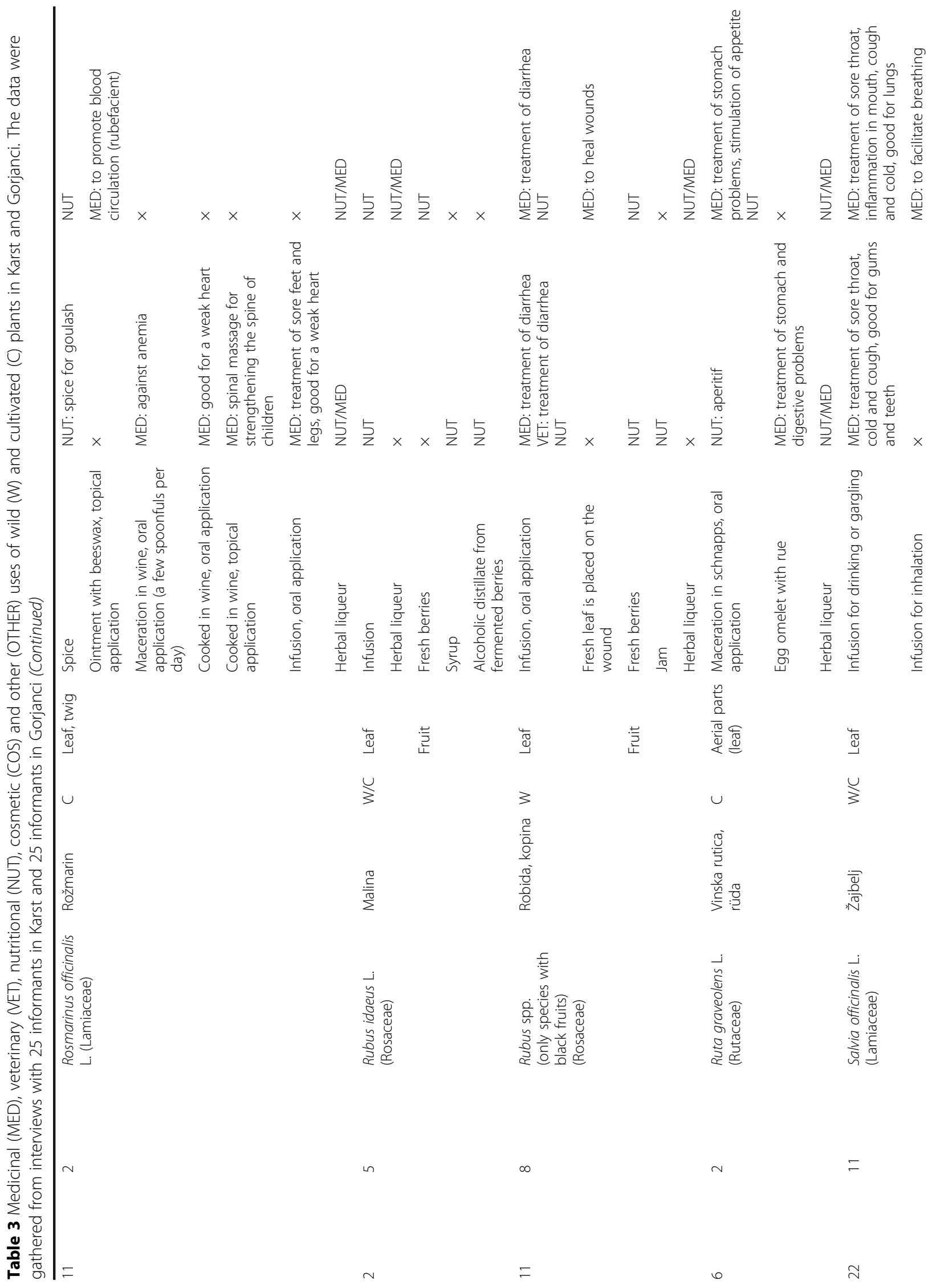




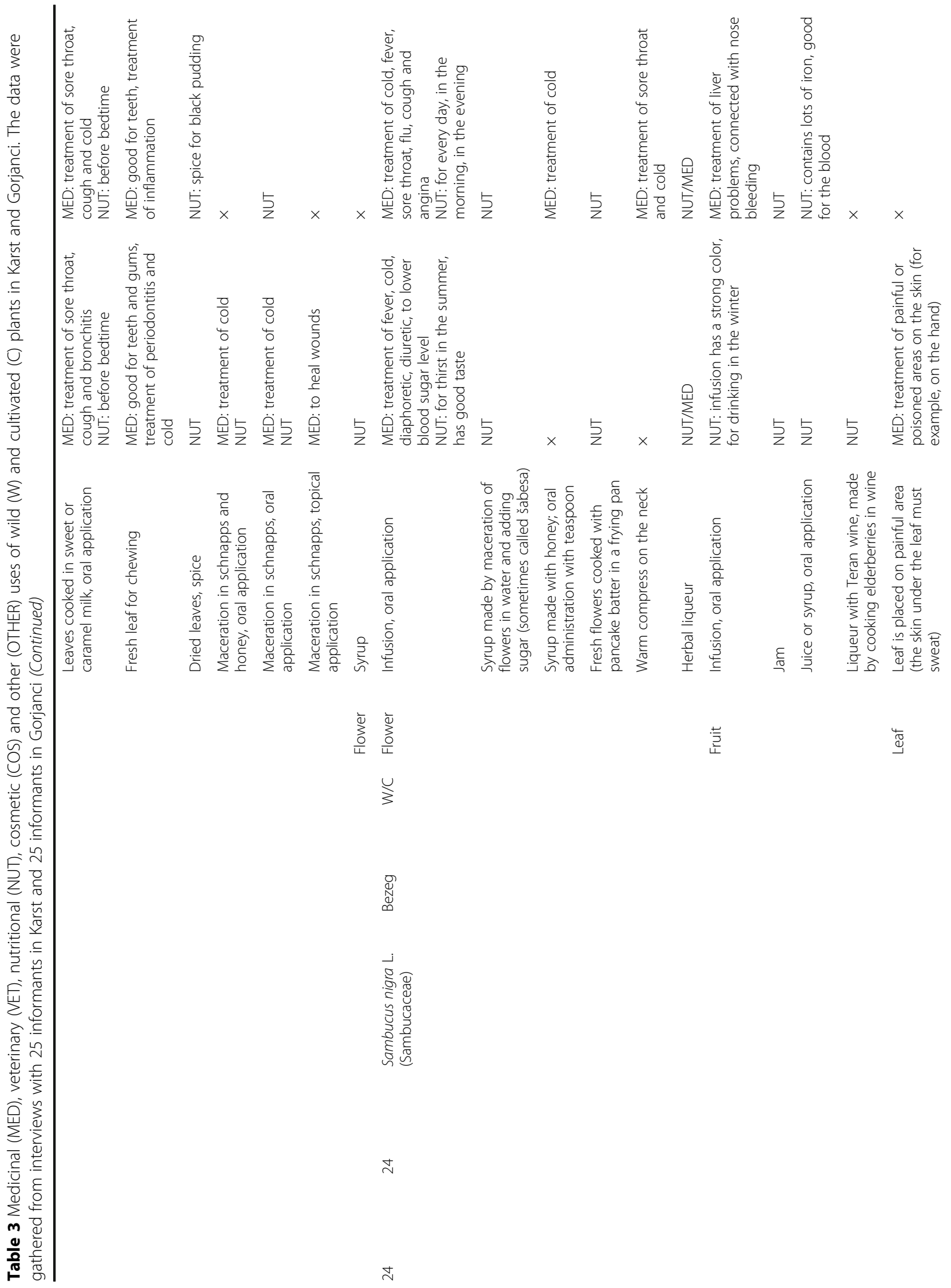




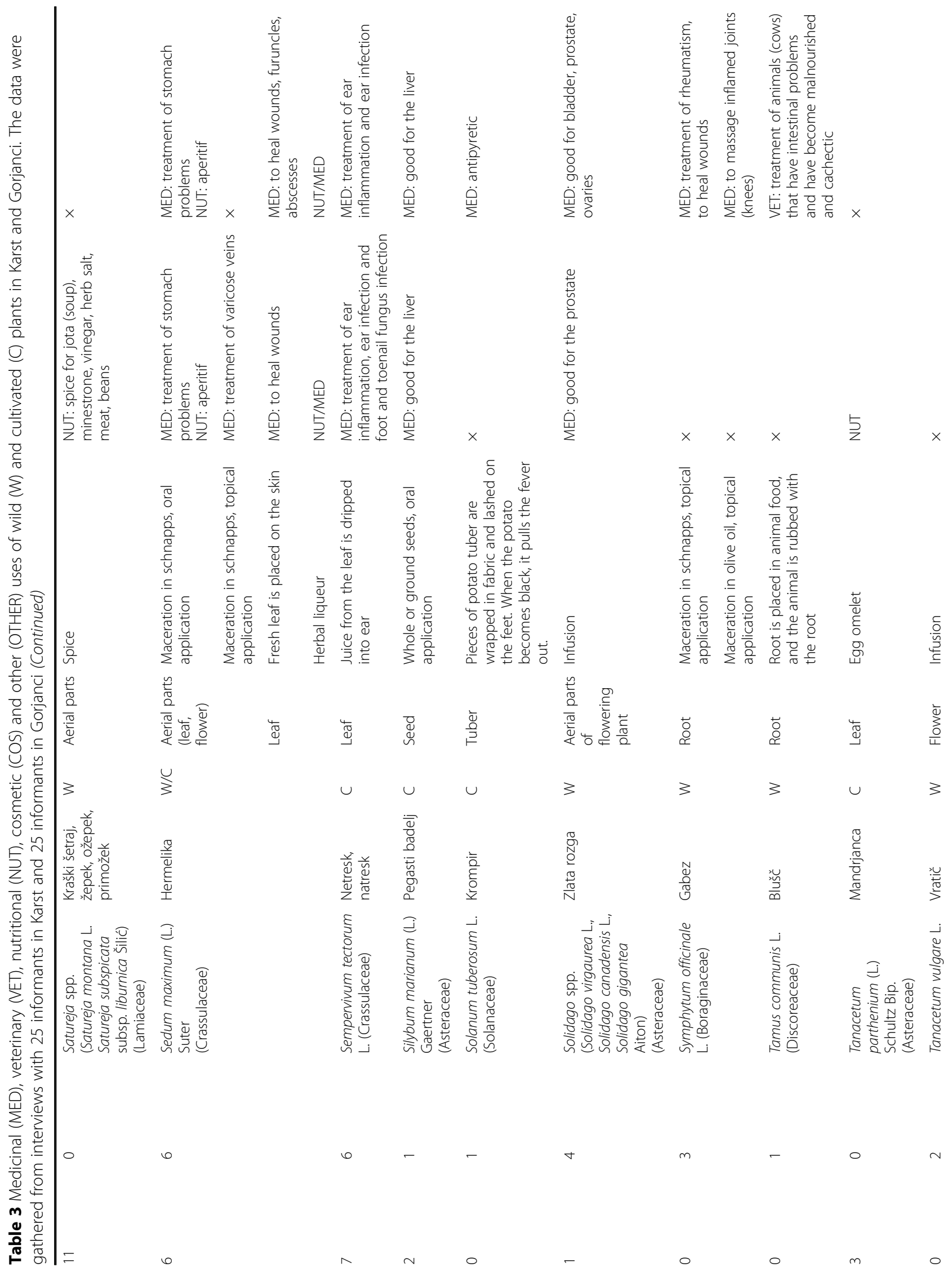




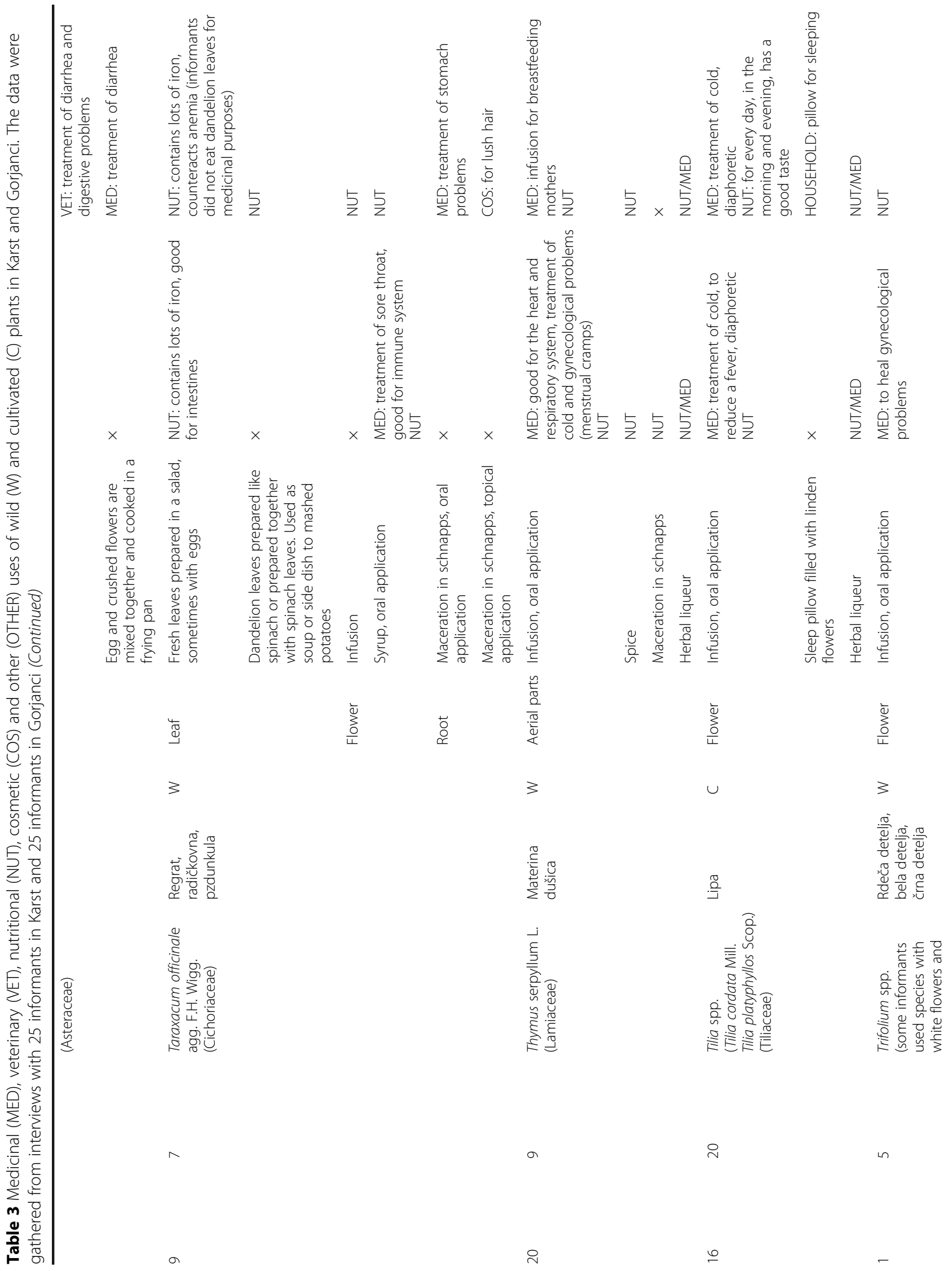




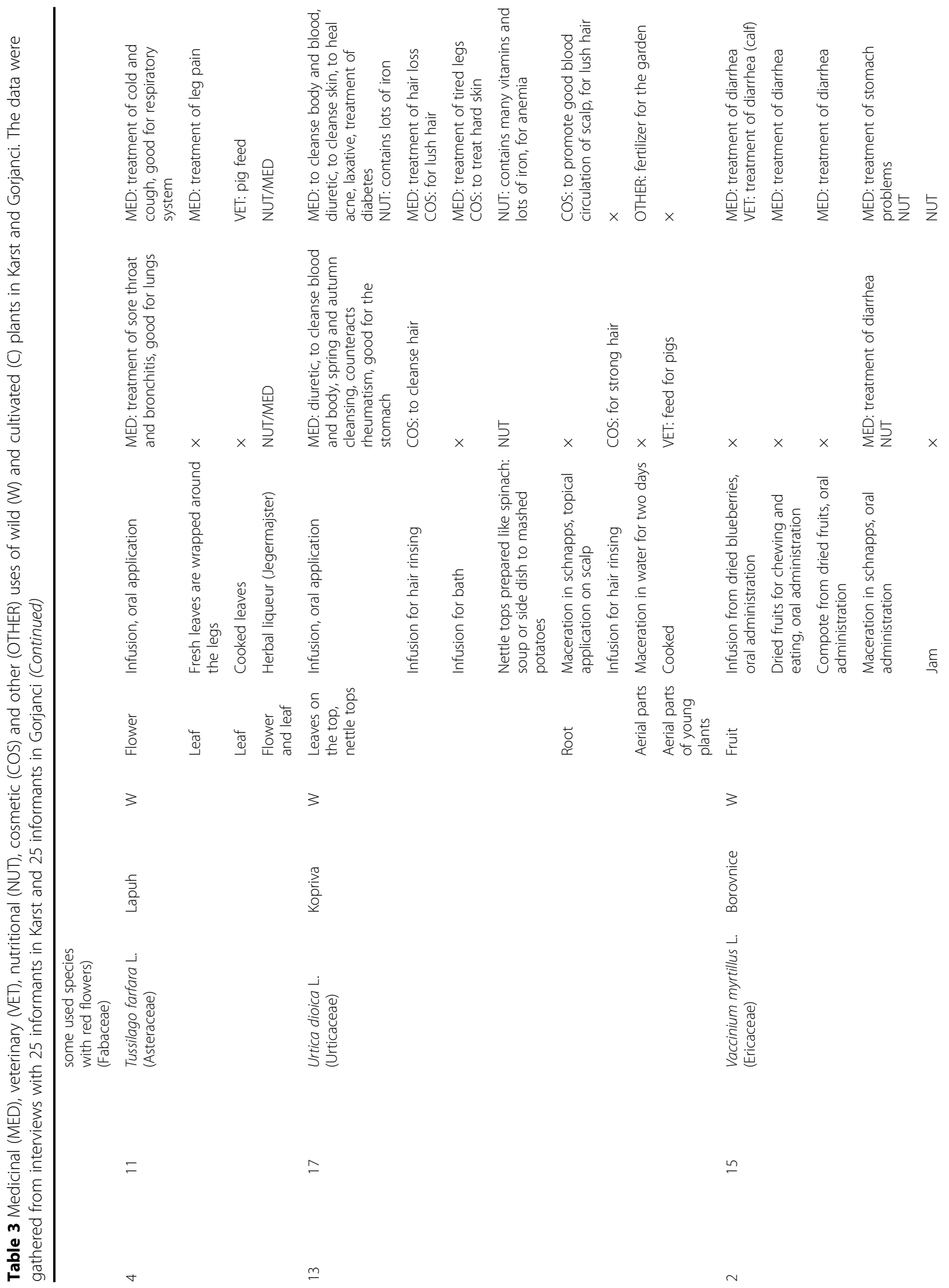




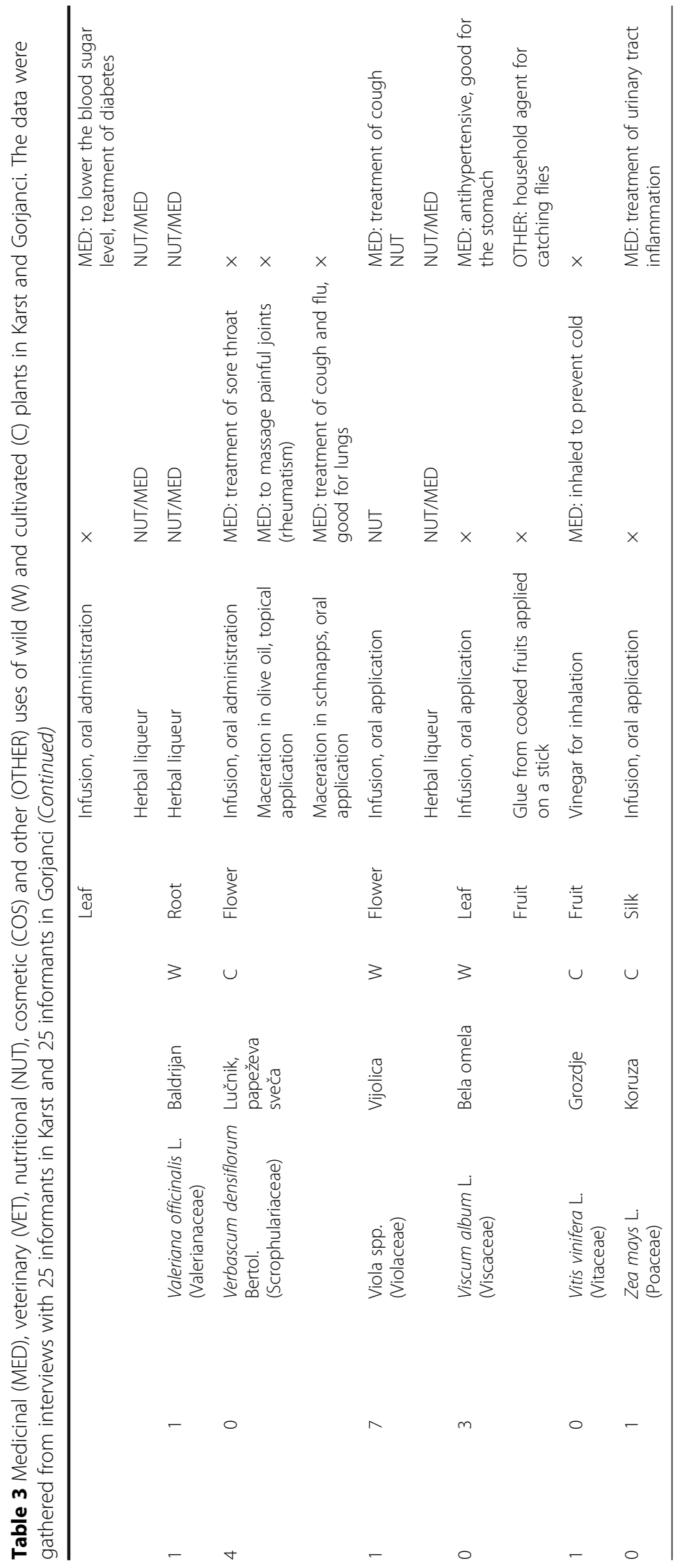


Table 4 List of plants reported by at least 3 informants in Karst or Gorjanci, with their frequency, rank and Smith's salience index

\begin{tabular}{|c|c|c|c|c|c|c|c|}
\hline \multicolumn{4}{|l|}{ Karst } & \multicolumn{4}{|l|}{ Gorjanci } \\
\hline Plant & Freq. & Rank & Smith's S & Plant & Freq. & Rank & Smith's S \\
\hline Sambucus nigra & 24 & 4.5 & 0.794 & Sambucus nigra & 24 & 6.38 & 0.694 \\
\hline Salvia officinalis & 22 & 11.45 & 0.448 & Achillea millefolium & 20 & 10 & 0.462 \\
\hline Rosa spp. & 22 & 10.36 & 0.491 & Tilia spp. & 20 & 7.65 & 0.541 \\
\hline Thymus serpyllum & 20 & 7.05 & 0.552 & Matricaria chamomilla & 19 & 10.05 & 0.465 \\
\hline Mentha spp. & 18 & 8.22 & 0.458 & Urtica dioica & 17 & 8.24 & 0.398 \\
\hline Melissa officinalis & 18 & 8.17 & 0.475 & Hypericum perforatum & 16 & 7.44 & 0.478 \\
\hline Matricaria chamomilla & 16 & 11.44 & 0.329 & Rosa spp. & 16 & 17.25 & 0.200 \\
\hline Tilia spp. & 16 & 7.13 & 0.439 & Centaurium spp. & 15 & 11.07 & 0.376 \\
\hline Achillea millefolium & 14 & 10.29 & 0.328 & Vaccinium myrtillus & 15 & 14.67 & 0.259 \\
\hline Urtica dioica & 13 & 9.85 & 0.300 & Fragaria vesca & 13 & 11.92 & 0.257 \\
\hline Crataegus spp. & 13 & 9.08 & 0.335 & Arnica montana & 12 & 14.08 & 0.227 \\
\hline Foeniculum vulgare & 13 & 12.69 & 0.241 & Calendula officinalis & 12 & 11.25 & 0.296 \\
\hline Juniperus communis & 12 & 12.5 & 0.225 & Primula vulgaris & 12 & 8.5 & 0.301 \\
\hline Satureja spp. & 11 & 9.64 & 0.252 & Tussilago farfara & 11 & 11.09 & 0.235 \\
\hline Centaurium spp. & 11 & 12.36 & 0.216 & Salvia officinalis & 11 & 10.45 & 0.245 \\
\hline Hypericum perforatum & 11 & 11.45 & 0.243 & Equisetum arvense & 10 & 14.8 & 0.203 \\
\hline Rosmarinus officinalis & 11 & 11.36 & 0.224 & Betula pendula & 10 & 16.3 & 0.158 \\
\hline Rubus spp. & 11 & 12.64 & 0.202 & Picea abies & 10 & 13.2 & 0.200 \\
\hline Prunus spinosa & 10 & 11.7 & 0.207 & Thymus serpyllum & 9 & 9.22 & 0.228 \\
\hline Plantago spp. & 10 & 11.4 & 0.208 & Juglans regia & 9 & 20.67 & 0.096 \\
\hline Laurus nobilis & 9 & 16.56 & 0.087 & Juniperus communis & 9 & 19.33 & 0.121 \\
\hline Taraxacum officinale agg. & 9 & 10 & 0.178 & Plantago spp. & 9 & 12.89 & 0.192 \\
\hline Calendula officinalis & 9 & 10.78 & 0.197 & Rubus spp. & 8 & 15.38 & 0.157 \\
\hline Cornus mas & 8 & 13.5 & 0.149 & Mentha spp. & 8 & 8 & 0.229 \\
\hline Origanum majorana & 8 & 9.13 & 0.182 & Viola spp. & 7 & 9.86 & 0.178 \\
\hline Artemisia spp. & 7 & 14.14 & 0.122 & Taraxacum officinale agg. & 7 & 21.86 & 0.095 \\
\hline Lavandula spp. & 7 & 11.14 & 0.162 & Carum carvi & 7 & 12.71 & 0.166 \\
\hline Sempervivum tectorum & 7 & 16 & 0.096 & Melissa officinalis & 7 & 8.43 & 0.209 \\
\hline Picea abies & 6 & 13.33 & 0.080 & Pulmonaria officinalis & 7 & 11.29 & 0.184 \\
\hline Asparagus spp. & 6 & 12.5 & 0.079 & Sempervivum tectorum & 6 & 13.83 & 0.110 \\
\hline Althaea officinalis & 6 & 13.67 & 0.091 & Potentilla erecta & 6 & 18.83 & 0.097 \\
\hline Ruta graveolens & 6 & 18.67 & 0.077 & Sedum maximum & 6 & 18 & 0.088 \\
\hline Sedum maximum & 6 & 12.67 & 0.103 & Crataegus spp. & 6 & 7.83 & 0.167 \\
\hline Arnica montana & 6 & 12.17 & 0.108 & Artemisia spp. & 6 & 22.67 & 0.068 \\
\hline Robinia pseudacacia & 5 & 20.4 & 0.028 & Quercus spp. & 6 & 19 & 0.077 \\
\hline Fragaria vesca & 5 & 15.4 & 0.087 & Trifolium spp. & 5 & 11.6 & 0.106 \\
\hline Aloysia citrodora & 5 & 13 & 0.073 & Pimpinella anisum & 5 & 9.4 & 0.138 \\
\hline Prunus avium & 4 & 17.25 & 0.016 & Prunus spinosa & 5 & 12.2 & 0.109 \\
\hline Tussilago farfara & 4 & 15.5 & 0.069 & Rubus idaeus & 5 & 12.8 & 0.100 \\
\hline Anthyllis vulneraria & 4 & 8.25 & 0.117 & Bellis perennis & 4 & 12 & 0.104 \\
\hline Levisticum officinale & 4 & 13 & 0.07 & Solidago spp. & 4 & 13 & 0.085 \\
\hline Verbascum densiflorum & 4 & 15.25 & 0.081 & Origanum vulgare & 4 & 9.75 & 0.068 \\
\hline Ocimum basilicum & 3 & 10.33 & 0.061 & Castanea sativa & 4 & 17.25 & 0.055 \\
\hline
\end{tabular}


Table 4 List of plants reported by at least 3 informants in Karst or Gorjanci, with their frequency, rank and Smith's salience index (Continued)

\begin{tabular}{llllllll}
\hline Gentiana lutea & 3 & 14 & 0.055 & Allium ursinum & 4 & 17.25 & 0.035 \\
Aesculus hippocastanum & 3 & 8.67 & 0.067 & Symphytum officinale & 3 & 13.33 & 0.055 \\
Carum carvi & 3 & 18.67 & 0.022 & Berberis vulgaris & 3 & 9.33 & 0.060 \\
Tanacetum parthenium & 3 & 17.33 & 0.010 & Viscum album & 3 & 24 & 0.028 \\
Pimpinella anisum & 3 & 12.33 & 0.061 & Linum usitatissimum & 3 & 23 & 0.029 \\
Primula vulgaris & 3 & 16 & 0.054 & Robinia pseudacacia & 3 & 25 & 0.038 \\
& & & & Galium odoratum & 3 & 26 & 0.028 \\
\hline
\end{tabular}

Plant species that were reported in only one of the two regions are printed in bold

several categories. The most frequently reported uses of plants were medicinal and nutritive: 81 plants were used as medicine, and 63 plants were used as food. Purely medicinal use was reported for 29 plants, purely nutritive use was reported for 11 plants, and a combination of medicinal and nutritive uses was reported for 52 plants. Other uses were less frequently reported: 17 plants were used for animal healthcare and 8 for cosmetic use. These uses were almost always mentioned together with nutritive or medicinal use.

\section{Comparison of plants reported in Karst and Gorjanci}

A comparison of the frequency distributions of the plants reported in Karst and Gorjanci (Fig. 2) showed that there were plants reported with similar or different frequencies in both regions. The 54 plants with a low frequency (mentioned by fewer than 7 informants in both regions) (Fig. 2, section D) were not included in this comparison. The plants whose frequency in one region was 3-fold higher than that in the other region were considered typical for that region. The plants that

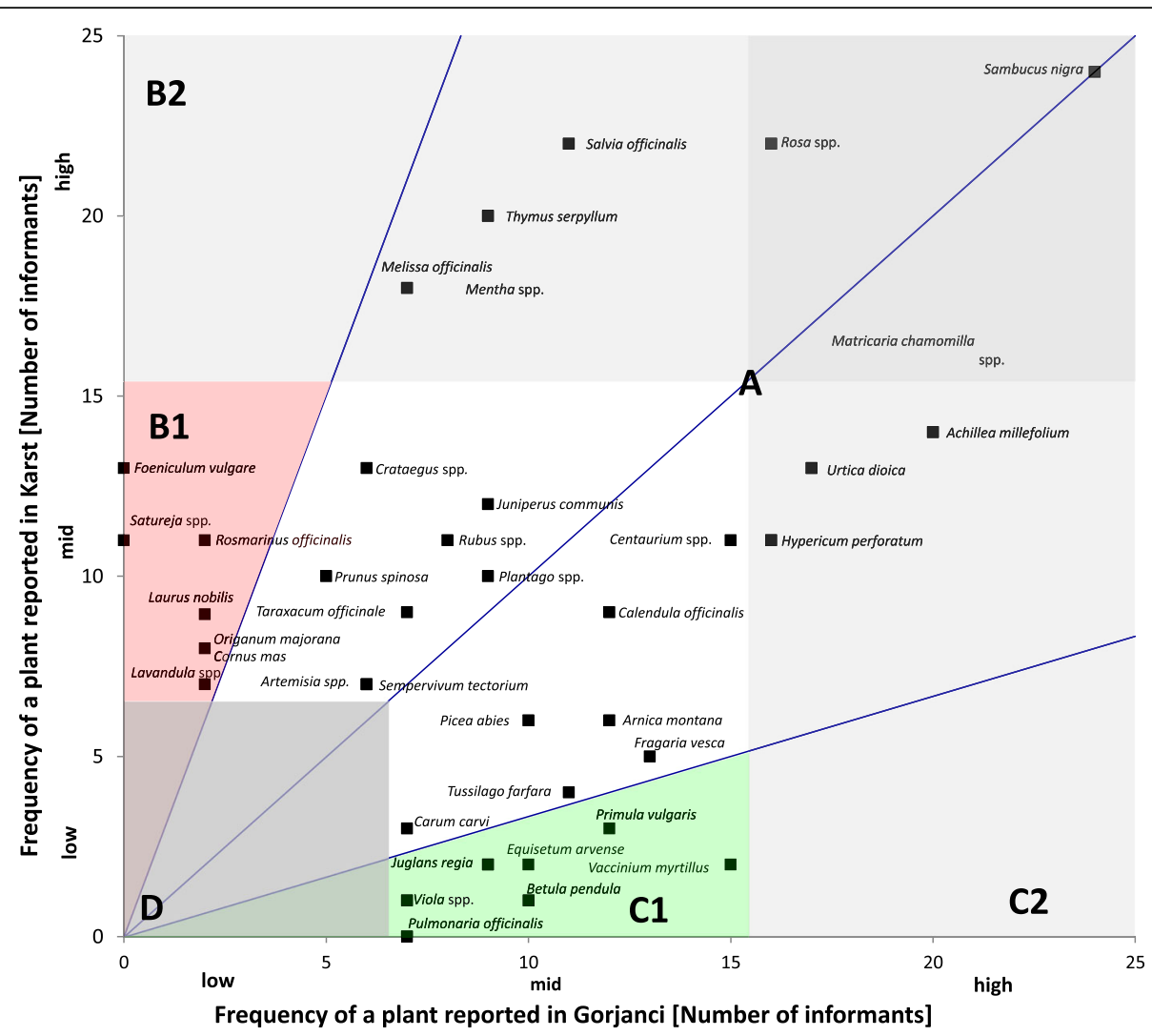

Fig. 2 Comparison of the frequency distribution of plants reported by 25 informants in Gorjanci and 25 informants in Karst. Frequencies below 7 are considered low, those from 7 to 15 mid, and those from 16 to 25 high. Plants that were reported by at least 7 informants in one region are represented by a dot with the plant's scientific name. Due to the high number of plants, those with frequencies lower than 7 in both regions are not represented by a dot; they lie in section $D$. The middle blue line represents plants with equal frequencies in both regions. The other blue lines represent plants with frequencies that were threefold higher in one region than in the other 
were typical for Karst were Foeniculum vulgare, Satureja spp., Rosmarinus officinalis, Laurus nobilis, Cornus mas, Origanum majorana and Lavandula spp. (Fig. 2, section B1). The plants that were typical for Gorjanci were Vaccinium myrtillus, Primula vulgaris, Equisetum arvense, Betula pendula, Juglans regia, Pulmonaria officinalis and Viola spp. (Fig. 2, section $\mathrm{C} 1$ ). Of the plants with a high frequency (mentioned by more than 15 informants in at least one region), no plants were typical for only one region (Fig. 2, sections B2 and C2). In both regions, 25 plants were reported equally or up to 3 -fold higher in one region than in the other (Fig. 2, plants in section A). These plants were considered regionally non-typical.

Laurus nobilis, Rosmarinus officinalis, and Origanum majorana were typical for Karst but were also reported in Gorjanci. These plants are part of the Mediterranean flora and are somewhat cold sensitive; therefore, they are more widely and easily cultivated in house gardens in Karst due to suitable growing conditions. They were mostly used as kitchen spices. Satureja spp., Cornus mas and Foeniculum vulgare were also typical plants for Karst and were not reported in Gorjanci. They grow wild in Karst but not in Gorjanci [67]. Foeniculum vulgare was also sometimes cultivated in house gardens in Karst for easier accessibility. Lavandula spp. was also typical for Karst. It was mostly used as an ornamental plant, but two informants in Karst reported that they were cultivating Lavandula spp. in fields and wanted to start producing lavender essential oil. It seems that Lavandula spp. has become an interesting plant for small businesses in Karst in recent years due to suitable growing conditions [68]. Therefore, it is very likely that Lavandula spp. was more frequently reported in Karst than in Gorjanci due to this plant's growing popularity. Guštin Grilanc also reported the use of the above-mentioned seven plants in Karst [30], but Lokar and Poldini reported only the use Satureja montana in Trieste Karst [29].

Vaccinium myrtillus, Equisetum arvense, Betula pendula and Pulmonaria officinalis were typical for Gorjanci and were rarely or not mentioned in Karst. This finding is probably because they grow wild in Gorjanci but are scarce in Karst [67]. Makarovič reported the use of the above-mentioned plants in Dolenjska and Bela Krajina [32]. Lokar and Podini reported only the use of Pulmonaria officinalis in Trieste Karst [29], and Guštin Grilanc reported only Equisetum arvense in Karst [30].

Primula vulgaris and Viola spp. have a wide distribution area in Slovenia and grow in both research areas (Karst and Gorjanci) [67]. Therefore, it was unexpected that these plants were observed to be typical for Gorjanci in our research. Makarovič did not report their use in
Dolenjska or Bela Krajina [32], but Guštin Grilanc reported the use of both plants in Karst; Lokar and Poldini also reported the use of Primula vulgaris in Trieste Karst [29].

This comparison indicates that there is a relatively homogeneous tradition of medicinal plant use in both areas, with minor regional differences. The regional differences for wild-collected plants are mostly due to ecological availability (all plants were not ubiquitously available in Karst and Gorjanci). The importance of ecological availability for comparison was previously shown in a comparative study of wild food plant consumption in Italy [55]. In addition to ecological availability, suitable growing conditions (climate and soil) were also important or essential for the cultivation of medicinal plants. In this regard, vicinity to the Adriatic Sea and Mediterranean flora plays a major role for Karst; in contrast, the continental climate in Gorjanci prevents the cultivation of cold-sensitive plants. We did not find that cultural differences played a role in the regional differences in the use of plant species.

\section{Medicinal use of plants in Karst and Gorjanci General data on the medicinal use of plants}

The plants that were reported in Karst and Gorjanci were grouped into 8 categories according to their therapeutic use (Table 5). The highest number of plants was used for the treatment of gastrointestinal disorders, respiratory system disorders and skin diseases. These categories also had the highest number of use reports. This finding is comparable to recent reports from southern Italy [40-42] and to reports from Adam Fisher, who collected traditional uses of plants in western Ukraine in the 1930s [69]. However, the distribution of uses in Bosnia and Herzegovina was slightly different, with urogenital indications being the most frequent $[66,70]$. The differences may be due to different methodologies or conditions in the region. The informants also reported using plants for genitourinary system disorders, miscellaneous infections, and musculoskeletal system disorders. The informants made the lowest number of reports for the treatment of heart, blood and circulatory system disorders, and they used the lowest number of plants to treat nervous system disorders. For different diseases, we observed different ratios between the number of reports and the number of plants: e.g., for the treatment of ear infection, we obtained 12 reports on the use of only one plant (in both regions); in contrast, 10 informants reported 7 different plants for the treatment of fever and 6 informants reported 6 different plants for the treatment of leg pain. 


\section{Differences in the medicinal use of plants in Karst and Gorjanci}

Differences in the reported medicinal use (indication) of some frequently collected plants were observed between Karst and Gorjanci. These regional differences could be explained by cultural differences, which were possibly due to proximity to neighboring areas. Matricaria chamomilla was used by 16 informants in Karst and 19 in Gorjanci. While most informants in Karst reported its use as a sedative (calmative) (K: $7 ; \mathrm{G}: 1)$, most of the Gorjanci informants reported its use for the treatment of respiratory infections (cold, flu, bronchitis, sore throat, or cough) (K: 1; G: 6), sore eyes (K: 2; G: 9), dysmenorrhea (K: $1 ; \mathrm{G}: 4$ ) or as a carminative (K: $5 ; \mathrm{G}: 13$ ). The difference between the regions was statistically significant (Fisher's exact test $p=0.010$ ). Lokar and Poldini also reported that $M$. chamomilla was used as a sedative in Trieste Karst and Istria [29], but Guštin Grilanc did not report this use in Karst [30]. Similarly, some ethnobotanical studies in Austria and Croatia reported that $M$. chamomilla was used as a sedative $[56,71]$, but some did not $[37,72]$. M. chamomilla was widely reported as a sedative in Italy $[40,73,74]$.

Altogether, 25 different plants were used as a carminative: 16 in Karst and 21 in Gorjanci. The treatment of poor digestion, spasms, stomach pain, and flatulence (carminative) was more frequently reported with Juniperus communis (G: 5; K: 9) in Karst and with Juglans regia (G: 6; K: 0), Centaurium spp. (G: 12; K: 5) and $M$. chamomilla (G: 13; K: 5) in Gorjanci; this difference was statistically significant (Fisher's exact test $p=0.024$ ). Lokar and Poldini did not mention the medicinal use of J. communis or J. regia in Trieste Karst, but they reported the medicinal use of infusion of Centaurium erythraea as a bitter tonic in Istria and as a decoction for the treatment of gastritis in Trieste Karst. In that study, decoction of Satureja montana was reported as a bitter tonic in Trieste Karst and alcoholic macerate as a tonic aromatic in Trieste Karst and Istria [29]; in our study, the informants in Karst reported only the nutritive use of Satureja spp.

Among the 8 medicinal plants that were reported for the treatment of diarrhea, Vaccinium myrtillus was the only plant that was reported by more than two informants. Its antidiarrheal use was reported by 10 informants, and most of the reports were from Gorjanci (K: 1; G: 9). $V$. myrtillus was more frequently mentioned in Gorjanci than in Karst (G: 15; K: 2), which is probably due to the scarcity of $V$. myrtillus in Karst and its presence in Gorjanci [67]. In the previous studies, the use of $V$. myrtillus was also not reported in Karst [30] or Trieste Karst [29] but was reported in Dolenjska and Bela Krajina, where it was also used for the treatment of diarrhea and stomachache [32].
Sambucus nigra was the most frequently mentioned plant (K: 24; G: 24). While most of the informants in Gorjanci reported its use for the treatment of respiratory infections (cold, flu, angina, or high fever, and as a diaphoretic) (G: 14; K: 5), most of the informants in Karst used it merely for nutritive purposes (G: 10; K: 18); this difference was statistically significant (Fisher's exact test $p=0.017$ ). Lokar and Poldini also did not report any medicinal use of S. nigra in Trieste Karst [29], but Guštin Grilanc reported its use against cough and cold in Karst [30]. In Dolenjska and Bela Krajina, its use was reported for sore throat, cough, cold, and high fever [32].

Salvia officinalis was reported in both regions for gargling and for the treatment of sore throat, mouth infection, and mouth inflammation (K: 11; G: 9) but was more frequently reported for the treatment of colds in Karst than in Gorjanci (K: 9; G: 2). S. officinalis, S. nigra, and Tilia spp. were the most frequently reported plants used for the treatment of colds. Tilia spp. was reported in both regions (K: 7; G: 4); S. officinalis was more frequently reported in Karst (K: 9; G: 2); and $S$. nigra was more frequently reported in Gorjanci (G: $11 ; \mathrm{K}: 3)$. Rosa spp. was seldom reported for the treatment of colds (G: 3; K: 2). Its use was more often reported merely due its nutritive value (G: 19; K: 12), and some informants reported that it was beneficial due to its (high) content of vitamin C (G: 7; K: 6).

\section{Continuity between nutritive and medicinal use}

In a number of plants, medicinal and nutritive uses were interconnected because approximately $50 \%$ of the plants were reported for both medicinal and nutritive purposes. Frequently, the same informant reported medicinal and nutritive uses of the same plant, plant part and plant preparation. In addition, properties that promote health, e.g., a high content of vitamin $\mathrm{C}$, were also reported for plants. There seems to be a continuous passage between the nutritive and medicinal uses of plants since it is the informant's intended use that determines whether the plant is a food or a medicine.

Four plants were reported for use in association with the urinary tract: Urtica dioica, Asparagus spp., Equisetum arvense and Betula pendula. A comparison of their use shows that some plants were more often reported as food, and some were more commonly used for the treatment of urinary infections (Table 6). For the above-mentioned plants, the informants also reported properties such as cleansing of the body, blood and kidneys and diuretic properties, which were mentioned together with purely nutritive or purely medicinal uses. Some plants were predominantly used for one purpose or the other. Two informants who used $E$. arvense for nutritive purposes added it to an herbal liqueur made from many plants ("Jegermajster"). 
Table 5 Categories of medicinal use of plants in Karst and Gorjanci with the number of reports and plants in each region

\begin{tabular}{|c|c|c|c|c|c|c|}
\hline Disease or action of the medicine & $\begin{array}{l}\text { No. of plants } \\
\text { reported } \\
\text { in Karst }\end{array}$ & $\begin{array}{l}\text { No. of reports } \\
\text { in Karst }\end{array}$ & $\begin{array}{l}\text { No. of plants } \\
\text { reported } \\
\text { in Gorjanci }\end{array}$ & $\begin{array}{l}\text { No. of reports } \\
\text { in Gorjanci }\end{array}$ & $\begin{array}{l}\text { No. of plants } \\
\text { reported in Karst } \\
\text { and Gorjanci }\end{array}$ & $\begin{array}{l}\text { No. of reports } \\
\text { in Karst } \\
\text { and Gorjanci }\end{array}$ \\
\hline Respiratory system disorders & 17 & 58 & 19 & 88 & 26 & 146 \\
\hline Cold & 9 & 28 & 12 & 33 & 16 & 61 \\
\hline Cough & 5 & 9 & 12 & 21 & 14 & 30 \\
\hline Sore throat & 7 & 12 & 6 & 14 & 10 & 26 \\
\hline "Good for lungs" and "good for respiratory system" & 3 & 4 & 5 & 8 & 7 & 12 \\
\hline Bronchitis & 4 & 4 & 2 & 3 & 5 & 7 \\
\hline Flu & 1 & 1 & 3 & 3 & 4 & 4 \\
\hline Asthma & 0 & 0 & 2 & 2 & 2 & 2 \\
\hline Breathing problems & 0 & 0 & 2 & 2 & 2 & 2 \\
\hline Pneumonia & 0 & 0 & 1 & 1 & 1 & 1 \\
\hline Angina & 0 & 0 & 1 & 1 & 1 & 1 \\
\hline Gastrointestinal disorders & 18 & 50 & 25 & 87 & 29 & 137 \\
\hline $\begin{array}{l}\text { Carminative (digestive problems, spasms, stomach } \\
\text { pain, and flatulence) }\end{array}$ & 16 & 43 & 21 & 67 & 25 & 110 \\
\hline Against diarrhea & 4 & 6 & 7 & 15 & 9 & 21 \\
\hline Appetite stimulation & 1 & 1 & 2 & 2 & 3 & 3 \\
\hline Laxative & 0 & 0 & 2 & 3 & 2 & 3 \\
\hline Skin diseases & 12 & 35 & 14 & 59 & 20 & 94 \\
\hline Wounds & 10 & 17 & 8 & 30 & 14 & 47 \\
\hline Burns and sunburns & 3 & 7 & 3 & 10 & 3 & 17 \\
\hline Furuncles and abscess & 0 & 0 & 4 & 7 & 4 & 7 \\
\hline Warts & 2 & 3 & 1 & 2 & 2 & 5 \\
\hline Contusions and bruises & 3 & 3 & 2 & 2 & 3 & 5 \\
\hline Rash and eczema & 1 & 1 & 2 & 2 & 2 & 3 \\
\hline Rubefacient & 1 & 2 & 1 & 1 & 2 & 3 \\
\hline Scabs & 1 & 1 & 1 & 1 & 2 & 2 \\
\hline Stings & 0 & 0 & 2 & 2 & 2 & 2 \\
\hline Snake bites & 1 & 1 & 0 & 0 & 1 & 1 \\
\hline Sweaty feet & 0 & 0 & 1 & 1 & 1 & 1 \\
\hline Inflamed nipples & 0 & 0 & 1 & 1 & 1 & 1 \\
\hline Genitourinary system disorders & 9 & 24 & 11 & 39 & 14 & 63 \\
\hline Diuretic, "cleansing of body, kidneys and blood" & 4 & 14 & 6 & 22 & 8 & 36 \\
\hline Gynecological problems & 5 & 10 & 5 & 8 & 6 & 18 \\
\hline Urinary tract inflammation & 0 & 0 & 5 & 9 & 5 & 9 \\
\hline Miscellaneous infections & 6 & 24 & 12 & 32 & 13 & 56 \\
\hline Ear infection & 1 & 7 & 1 & 5 & 1 & 12 \\
\hline Fever & 2 & 2 & 7 & 8 & 7 & 10 \\
\hline Mouth inflammation & 1 & 5 & 2 & 5 & 2 & 10 \\
\hline Eye infection & 2 & 1 & 2 & 8 & 3 & 9 \\
\hline Diaphoretic & 2 & 5 & 1 & 3 & 2 & 8 \\
\hline Anthelmintic & 1 & 3 & 2 & 3 & 2 & 6 \\
\hline Fungal nail infection & 1 & 1 & 0 & 0 & 1 & 1 \\
\hline
\end{tabular}


Table 5 Categories of medicinal use of plants in Karst and Gorjanci with the number of reports and plants in each region (Continued)

\begin{tabular}{|c|c|c|c|c|c|c|}
\hline Musculoskeletal system disorders & 9 & 15 & 11 & 20 & 14 & 35 \\
\hline Muscle or joint pain in various body parts & 4 & 5 & 2 & 6 & 5 & 11 \\
\hline Rheumatism & 4 & 5 & 4 & 7 & 6 & 11 \\
\hline Pain in legs & 2 & 2 & 4 & 4 & 6 & 6 \\
\hline Pain in the back & 2 & 2 & 0 & 0 & 2 & 2 \\
\hline Pain in hands & 0 & 0 & 1 & 1 & 1 & 1 \\
\hline Weak spine of children & 1 & 1 & 0 & 0 & 1 & 1 \\
\hline Knee effusion & 0 & 0 & 1 & 1 & 1 & 1 \\
\hline Swollen legs & 0 & 0 & 1 & 1 & 1 & 1 \\
\hline Nervous system disorders & 6 & 18 & 5 & 17 & 9 & 35 \\
\hline Calmative & 5 & 15 & 5 & 11 & 7 & 26 \\
\hline Sleep disorders & 1 & 2 & 3 & 5 & 4 & 7 \\
\hline Epilepsy & 1 & 1 & 0 & 0 & 1 & 1 \\
\hline Depression & 0 & 0 & 1 & 1 & 1 & 1 \\
\hline Heart, blood and circulatory system disorders & 8 & 21 & 6 & 9 & 13 & 30 \\
\hline Heart trouble & 3 & 13 & 2 & 4 & 4 & 17 \\
\hline Varicose veins & 3 & 4 & 1 & 1 & 3 & 5 \\
\hline High blood pressure & 1 & 1 & 2 & 3 & 3 & 4 \\
\hline Anemia & 2 & 2 & 0 & 0 & 2 & 2 \\
\hline Hemorrhoids & 1 & 1 & 0 & 0 & 1 & 1 \\
\hline Against blood clotting & 0 & 0 & 1 & 1 & 1 & 1 \\
\hline
\end{tabular}

Groups of diseases are labeled in bold

The phenomenon of people using the same plants as food and as medicine has been observed in many cultures [75-78]. In theory, the basic characteristics of plants that influence their categorization are their nutritive value and medicinal or health benefits, which are beyond basic nutrition [79]. In practice, some constituents (e.g., vitamin C) have both nutritive and therapeutic benefits, and some plants that do not contain important nutrients are used as food (e.g., as herbal tea for refreshment). Furthermore, whether a plant is consumed as food or as medicine is also based on local beliefs, perceptions and intention of use [78]. The case of garlic, which became a legal matter in the European Court, demonstrates that the border between the use of a plant as a food and medicine can be unclear [80].

\section{Medicinal plants in animal healthcare}

Studies of ethnoveterinary medicine have been conducted in many European countries, and they are important for the preservation of traditional knowledge and the identification of alternatives for the treatment of animal diseases [81-84]. Our research did not focus on ethnoveterinary medicine, but a small number of medicinal plants used for animal health and welfare were reported in the interviews. The informants in Gorjanci and Karst mentioned the use of 14 plants in animal healthcare and three as animal feed (Table 3). The most frequently reported medicinal plants for animals were Matricaria chamomilla (K: 0; G: 6) and Quercus spp. (K: 1; G: 4); other plants were reported by one or two informants. In Gorjanci, infusion of M. chamomilla was

Table 6 Comparison of the reported uses of plants that were collected in Karst and Gorjanci

\begin{tabular}{|c|c|c|c|c|c|}
\hline \multirow[t]{2}{*}{ Plant } & \multicolumn{2}{|c|}{ No. of informants } & \multicolumn{3}{|c|}{ Reported uses in Karst and Gorjanci } \\
\hline & Karst & Gorjanci & Food & $\begin{array}{l}\text { Cleansing of the body, blood } \\
\text { and kidneys; diuretic properties }\end{array}$ & $\begin{array}{l}\text { Treatment of urinary } \\
\text { infections }\end{array}$ \\
\hline Urtica dioica & 13 & 17 & 14 & 15 & 0 \\
\hline Asparagus spp. & 6 & 0 & 6 & 5 & 0 \\
\hline Equisetum arvense & 2 & 10 & 2 & 10 & 10 \\
\hline Betula pendula & 0 & 6 & 0 & 6 & 6 \\
\hline
\end{tabular}


reported for the treatment of digestive problems in livestock; it was also given to cows after calving. The bark of Quercus spp. was reported for the treatment of diarrhea in livestock. M. chamomilla and Quercus spp. are among the most frequently mentioned species in European ethnoveterinary studies [83].

Most of the plants were reported for the treatment of gastrointestinal problems: in addition to the bark of Quercus spp., dried fruits of Vaccinium myrtillus (in calves), flowers of Tanacetum vulgare and leaves of Rubus spp. (species with black fruits) (in livestock) were reported for diarrhea; the infusion of flowers and herbs of Centaurium spp. (in livestock), roots of Gentiana lutea (in livestock), flowers of T. vulgare, flowers and herbs of M. chamomilla (in livestock) and schnapps macerate of Juglans regia were reported for the treatment of digestive problems; the oil macerate of Hypericum perforatum flowers was reported for the treatment of indigestion in hens that had eaten too much sand; Artemisia spp. was reported for the treatment of low appetite in livestock; and the root of Tamus communis was reported for the treatment of a cow with intestinal problems that became malnourished and cachectic. The infusion of Pimpinella anisum fruits was reported for the treatment of mastitis (udder inflammation) in cows. An informant in Gorjanci reported the use of bread with a few drops of essential oil from fermented berry cones of Juniper communis to treat a sick bullock, which immediately felt better and could stand up. Water extract from cooked leaves of $J$. regia was applied to a bullock's skin to protect the animal from horseflies. A schnapps macerate and a water infusion of Inula hirta flowers were reported for the treatment of a dog with a snake bite. Aerial parts of Cannabis sativa, acorns of Quercus spp. and cooked leaves of Tussilago farfara were reported as pig feed.

The use of nine medicinal plants was the same in humans and animals. In the case of Inula hirta and Juniperus communis, the informants illustrated and augmented their claims for the effectiveness of the medicinal plant with an example of treating a sick animal with the preparation of that plant. Similarly, an informant from Gorjanci emphasized the high medicinal value of Centaurium spp. by reporting that the animal (cow) was healthier if it fed on grass containing centaury. This statement could also be understood to mean that feeding is vital for animal welfare [84]. We did not observe the use of any important plants in animals, which was not previously reported in the above-mentioned literature.

\section{Medicinal preparations}

Informants in Karst and Gorjanci reported a high number of medicinal preparations for oral and topical applications (Tables 7 and 8). However, the large number of preparations does not reflect the relevance of use, as some
Table 7 Medicinal preparations for oral application reported in Karst and Gorjanci

\begin{tabular}{lll}
\hline Preparation method & No. of plants \\
\hline Fresh and dried & Dried fruits & 3 \\
plant material & Raw fruits & 1 \\
& Juice & 1 \\
& Leaf for chewing & 1 \\
& Seeds & 1 \\
& Bulb & 1 \\
Heat-processed & Infusion & 48 \\
plant material & Decoction & 1 \\
& Compote from dried fruits & 2 \\
& Leaves cooked in (caramel) milk & 2 \\
& Cooked in wine & 1 \\
& Roux soup with eggs and flowers & 1 \\
& Egg omelet with plant material & 3 \\
& Eggs cooked in a frying pan and & 1 \\
& sprinkled with flowers & 1 \\
Distillation & Essential oil \\
& Alcoholic distillate & 1 \\
Maceration & Maceration in schnapps & 16 \\
& Maceration in wine & 2 \\
& Syrup & 9 \\
\hline
\end{tabular}

preparations were reported by all informants and some by a single informant. The list merely reflects the versatility of the preparations described in the interviews.

For oral application, informants reported 15 different methods of preparing the plant material. Most of the methods included heat processing or maceration; the use of unprocessed fresh or dried plants was reported for only eight plants. Infusions, alcoholic macerates and syrups were the prevailing preparations for many of the reported plants; the remaining 12 preparations were specific for one to three plants (Table 7). Most of the preparations for topical application were reported for skin, and only a few preparations were reported for eyes, ears or lungs (Table 8). The large number of different skin preparations might be associated with the considerable number of plants reported for skin diseases, as 20 were reported in both regions (Table 5). The plants that were used for skin were mainly prepared by maceration in oil or schnapps, or fresh plant material was applied to the skin.

Alcoholic distillate ("brinjevec") and essential oil ("brinjevo olje") of Juniperus communis are of special interest because they have likely been known for centuries in the territory of Slovenia. "Brinjevec" is a protected spirit drink with a geographical indication; it was mentioned in 1689 by Janez Vajkard Valvasor in Die Ehre dess Hertzogthums Crain and is made by distilling fermented 
Table 8 Medicinal preparations for topical application reported in Karst and Gorjanci

\begin{tabular}{|c|c|c|c|}
\hline & Preparation method & & No. of plants \\
\hline \multirow[t]{14}{*}{ Skin } & \multirow[t]{3}{*}{ Fresh plant material } & $\begin{array}{l}\text { Fresh plant material is } \\
\text { placed on the skin }\end{array}$ & 10 \\
\hline & & Latex & 2 \\
\hline & & Resin & 1 \\
\hline & \multirow{7}{*}{$\begin{array}{l}\text { Heat-processed } \\
\text { plant material }\end{array}$} & Ointment made with lard & 2 \\
\hline & & Fried plant material & 1 \\
\hline & & $\begin{array}{l}\text { Poultice made from cooked } \\
\text { plant material }\end{array}$ & 2 \\
\hline & & Infusion for warm compress & 1 \\
\hline & & Infusion & 2 \\
\hline & & Infusion for bath & 3 \\
\hline & & Cooked in wine & 1 \\
\hline & \multirow[t]{2}{*}{ Distillation } & Essential oil & 1 \\
\hline & & Alcoholic distillate & 1 \\
\hline & \multirow[t]{2}{*}{ Maceration } & Maceration in oil & 5 \\
\hline & & Maceration in schnapps & 10 \\
\hline \multirow[t]{2}{*}{ Eyes } & $\begin{array}{l}\text { Heat-processed } \\
\text { plant material }\end{array}$ & $\begin{array}{l}\text { Infusion for eye rinsing } \\
\text { and compress }\end{array}$ & 1 \\
\hline & Fresh plant material & Seed is placed in eye & 1 \\
\hline \multirow[t]{2}{*}{ Lungs } & $\begin{array}{l}\text { Heat-processed } \\
\text { plant material }\end{array}$ & Infusion for inhalation & 3 \\
\hline & Fermentation & Vinegar for inhalation & 1 \\
\hline Ears & Fresh plant material & Juice is dripped into ear & 1 \\
\hline
\end{tabular}

juniper berries from J. communis. The side product of this distillation is an essential oil [85]. The medicinal use of the essential oil was reported in both regions; it was used internally and externally. The external use of distilled oil from $J$. communis was reported by Istro-Romanians in Žejane, northeastern Istria, Croatia [71]; Croatians living Čičarija, northern Istria, reported the internal use of the alcoholic distillate [72].

In Karst and Gorjanci, five women aged 65 to 87 years reported the medicinal use of three common Slovenian dishes: browned flour soup ("prežganka" in Slovene), egg omelet ("omleta" in Slovene; "frtalja" in Karst), and eggs cooked in a frying pan. The dishes were used medicinally for the treatment of gastrointestinal problems and dysmenorrhea when prepared with the following plants: Achillea millefolium, Ruta graveolens, Tanacetum vulgare and Matricaria chamomilla (Table 3). This information might be of special interest since the concomitant use of these plants and food (eggs) might alter the body's response to the medicine compared to using an infusion of the plant.

Two women aged 79 and 87 years from villages in the foothills of Gorjanci reported several unusual medicinal preparations made from plant, fungal, and animal materials: a necklace made from garlic cloves (Allium sativum) was used as an anthelmintic; pig feces was used to heal furuncles and abscesses; humane urine was used to disinfect wounds; pork cracklings (fried bacon cubes in lard) were used to heal scabs; snails were used to heal warts; and sour yeast (known as "kravajc" in Gorjanci) made from corn flour, millet chaff and wine foam was used to treat pain. A small loaf of "kravajc" was wetted with warm water and lashed on the sole of the foot to relieve foot pain ("kravajc pulled the pain out of the foot").

A few informants (K: 1; G: 3) reported the preparation of herbal liqueurs. They collected different plants from spring to autumn and macerated them in homemade schnapps. The informants in Gorjanci called this liqueur "jegermajster" (similar to the name of the commercial aperitif Jägermeister), and the informants in Karst called it "bitter". It was used for nutritive purposes and to treat digestive problems and stomachaches. The informants reported using the following plants for the liqueur: Achillea millefolium, Aesculus hippocastanum, Althaea officinalis, Anthyllis vulneraria, Arnica montana, Artemisia spp., Bellis perennis, Calendula officinalis, Castanea sativa, Centaurium spp., Equisetum arvense, Fragaria vesca, Galium odoratum, Hypericum perforatum, Juglans regia, Juniperus communis, Matricaria chamomilla, Melissa officinalis, Mentha spp., Plantago spp., Potentilla erecta, Primula vulgaris, Pulmonaria officinalis, Robinia pseudacacia, Rosmarinus officinalis, Rubus idaeus, Rubus spp. (species with black fruits), Ruta graveolens, Sambucus nigra, Thymus serpyllum, Tilia spp., Tussilago farfara, Vaccinium myrtillus, Valeriana officinalis, and Viola spp. (Table 3).

\section{Sources of knowledge about plants}

The transmission of knowledge about medicinal plants (which includes behaviors, attitudes, or technologies) is a complex process. We can distinguish between different transmission processes between individuals, e.g., from parent to child and between members of the same generation [86, 87]. Ethnobotanical studies have mainly focused on individuals as transmitters of knowledge; however, in literate societies, media such as books, television, journals and the internet are also important $[88,89]$ since this type of transmission can bring very rapid cultural change [87].

In Slovenia, many books were published about medicinal plants in the twentieth century, and they could easily influence the folk knowledge about plants. A general question, "Where did you get your knowledge about plants?" was posed to the informants to determine whether books or other media had influenced their knowledge. Media as non-oral sources were important for the botanical knowledge of the informants, as 20 informants in Karst and 12 in Gorjanci reported them. Books were 
frequently reported in both regions, whereas television, magazines, newspapers, the internet and radio were rarely reported (Table 9). Father Simon Ašič was the most

Table 9 Sources of knowledge about plants for informants in Karst and Gorjanci

\begin{tabular}{|c|c|c|c|}
\hline & & $\begin{array}{l}\text { No. of } \\
\text { informants } \\
\text { in Karst }\end{array}$ & $\begin{array}{l}\text { No. of } \\
\text { informants } \\
\text { in Gorjanci }\end{array}$ \\
\hline \multirow[t]{14}{*}{ Oral sources - relatives } & Mother & 8 & 9 \\
\hline & Father & 0 & 2 \\
\hline & Parents & 0 & 2 \\
\hline & Grandmother & 5 & 5 \\
\hline & Grandfather & 0 & 1 \\
\hline & Grandparents & 1 & 0 \\
\hline & Sister & 1 & 0 \\
\hline & Brother & 0 & 1 \\
\hline & Aunt & 1 & 0 \\
\hline & Uncle & 1 & 0 \\
\hline & Mother-in-law & 1 & 3 \\
\hline & Sister-in-law & 0 & 1 \\
\hline & Cousin (female) & 0 & 1 \\
\hline & Relatives (in general) & 1 & 0 \\
\hline \multirow{14}{*}{$\begin{array}{l}\text { Oral sources - } \\
\text { non-relatives }\end{array}$} & Neighbors & 0 & 3 \\
\hline & Neighbor - woman & 0 & 2 \\
\hline & Neighbor - man & 1 & 0 \\
\hline & Friends & 1 & 0 \\
\hline & Woman friend & 3 & 0 \\
\hline & Co-worker - woman & 2 & 2 \\
\hline & Older women & 0 & 2 \\
\hline & Older people & 0 & 1 \\
\hline & Doctor - woman & 0 & 1 \\
\hline & Doctor - man & 1 & 0 \\
\hline & Veterinarian - man & 0 & 1 \\
\hline & Herbalist - man & 1 & 0 \\
\hline & Herbalist - woman & 1 & 0 \\
\hline & Others (in general) & 0 & 2 \\
\hline \multirow[t]{6}{*}{ Oral sources - summary } & Total number & 29 & 39 \\
\hline & Relatives (in total) & 19 & 25 \\
\hline & Non-relatives (in total) & 10 & 14 \\
\hline & Women & 22 & 29 \\
\hline & Men & 4 & 5 \\
\hline & Unknown sex & 3 & 5 \\
\hline \multirow[t]{5}{*}{ Non-oral sources } & Books & 20 & 10 \\
\hline & TV & 1 & 3 \\
\hline & Magazine, newspaper & 3 & 0 \\
\hline & Internet & 1 & 2 \\
\hline & Radio & 0 & 2 \\
\hline
\end{tabular}

frequently mentioned author; 8 informants in Karst and 5 in Gorjanci reported his books [21, 23, 24]. This finding is in accordance with a survey conducted in seven pharmacies in northeastern Slovenia [34]. From the available publications associated with medicinal plants, most of the informants (43.1\%) reported reading the book Priročnik za nabiranje rastlin (English: Manual for wild collection of plants) by Father Simon Ašič [24]. In our study, Maria Treben was the second most reported author; two informants in Gorjanci and two in Karst reported her work Zdravje iz božje lekarne (English: Health through god's pharmacy) [25]. In the previously mentioned survey, $17.8 \%$ of the informants reported reading this book [34]. Although the majority of books on medicinal plants in the Slovene language were written by pharmacists, the two most popular authors were the two with no formal pharmaceutical education.

Among the plants reported by respondents in our study, there were no plants that had not been previously reported in the popular books published in Slovenian language in 20th century. Our results therefore support the claim [88] made already in the 19th century [90] that practically all plant species found in ethnomedicinal studies in Europe are based on knowledge from old herbals. However, new and interesting details on indications, modes of preparation, and cultural and ecological influences can be found.

The influence of modern phytotherapy on folk knowledge was observed in the terminology used by the informants in the interviews. In some cases, the informants used modern terms for diseases to describe the medicinal use of reported plants, e.g., diabetes, angina pectoris, epilepsy, or depression. Moreover, in some cases, the informants reported that some plants were beneficial due to their high content of iron, minerals or vitamins. In contrast, informants frequently reported that some medicinal plants were good for the blood, weak heart, treatment of women's problems, cleansing of blood and kidneys and other non-professional terms.

Individual people as oral sources were also important providers of botanical knowledge to the informants; 20 informants in Karst and 21 in Gorjanci reported at least one person as their teacher. It seems that women play a predominant role in the transmission of knowledge, as they were more frequently reported than men in both regions, although the sex of the source was sometimes not determined (Table 9). Relatives were more frequently reported than non-relatives (friends, co-workers, doctors, etc.), although the latter were often mentioned in both regions. Among all individual people, mothers were the most frequently reported source; eight informants in Karst and nine in Gorjanci mentioned them. Other important sources were grandmothers and friends in Karst and grandmothers, mothers-in-law and neighbors in Gorjanci. 


\section{Conclusions}

The information collected in Karst and Gorjanci and presented here provides insight into Slovenian ethnobotanical knowledge, which has received minimal study and documentation in the past. Karst and Gorjanci are two remote, rural areas where people are still connected to nature and knowledge about plants is important to their lives. There were relatively similar traditions of plant use in both areas; minor regional differences in wild-collected plants were observed, and these were mostly due to the ecological availability of the plants. The reported plants were mostly used for medicinal and nutritive purposes; it seems that it was the respondent's intention that determined whether the plant was used as food or as medicine since both purposes were reported for approximately $50 \%$ of the plants. Numerous and diverse preparations of medicinal plants were reported for oral and topical applications. The respondents were mostly elderly people with a mean age of 61 years in Karst and 69 years in Gorjanci; however, their knowledge about plants seemed to be influenced by media, most often popular books about medicinal plants that were published in the 20th century. The results of this study may be of interest to ethnobotanists interested in the uses of plants in countries of the former Yugoslavia and for further ethnobotanical investigations in literate societies, in which folk knowledge may already be influenced by media, such as books, television and the internet.

\section{Abbreviations \\ C: Cultivated; COS: Cosmetic use; G: Gorjanci; K: Karst; MED: Medicinal use; NUT: Nutritive use; OTHER: Other uses; VET: Veterinary use; W: Wild}

\section{Acknowledgments \\ The authors would like to thank the informants from villages neighboring the birthplace of one of the authors, Mateja Lumpert, in the foothills of Gorjanci and from villages in Karst. The authors would also like to thank Assist. Prof. Dr. Uršula Lipovec Čebron of the Faculty of Arts, University of Ljubljana, who inspired the authors while sharing her knowledge about anthropological research.}

\section{Funding}

This study was funded by the Slovenian Research Agency (Program No. P4-0127). This work is the sole responsibility of the authors and does not represent the opinion of the organization providing financial support.

\section{Availability of data and materials}

Not applicable.

\section{Authors' contributions}

The authors participated in the design of the study and writing the paper. Both authors read and approved the final manuscript.

\section{Competing interests}

The authors declare that they have no competing interests.

\section{Consent for publication}

Not applicable. This manuscript does not include details, images, or videos relating to informants.

Ethics approval and consent to participate

Prior informed consent was obtained from all informants in this study.
Received: 7 September 2016 Accepted: 13 February 2017

Published online: 23 February 2017

\section{References}

1. Janžekovič B. Slovenske knjige o zdravilnih rastlinah. In: Predin Š, editor. Slovenski farmacevti v naravoslovju : zbornik referatov s simpozija ob 200 letnici rojstva Henrika Freyerja (1802-1866). Maribor: Mariborske lekarne; 2002. p. 273-320.

2. Zupan SZ. Zdravnik in botanik Pietro Andrea Mattioli. Glasilo Zdravniške zbornice Slovenije. 2001;10:68-70.

3. Dolenc M. Bibliografija rokopisnih ljudsko-medicinskih bukev in zapisov s slovenskega etničnega območja. Slovenski Etnograf. 1983;31:31-74.

4. Volčič J. Domači zdravnik. Celovec: Družba sv. Mohora; 1874

5. Cilenšek M. Naše škodljive rastline v podobi in besedi. Celovec: Družba sv. Mohorja; 1892

6. Naša zdravila in njih uporaba $\vee$ domačem zdravljenju. Ljubljana: Katoliška Bukvarna; 1914.

7. Navodila za nabiranje in sušenje divje rastočih zdravilnih rastlin. Maribor: Ljudski tisk; 1921.

8. Bevk $S$. Važnejše domače zdravilne rastline $: v$ besedi in podobi z navodilom, kako se nabirajo in suše. Ljubljana: Oblastni odbor Podmladka Rdečega križa; 1929.

9. Fatur L. Zel in plevel : slovar naravnega zdravilstva. Ljubljana: Jugoslovanska knjigarna; 1926.

10. Dvoŕáček F. Domači živinozdravnik : veliki svetovalec pri obolenju in ponesrečenju domačih živali : pomožna knjiga vsakega dobrega gospodarja in prijatelja živali pri obolenju konj, goveje živine, prašičev, drobnice, psov, mačk, kuncev in perutnine : zdravljenje s pomočjo zdravilnih rastlin in zelišč. Ljubljana: Umetniška propaganda; 1932.

11. Pearson RW. Zdravljenje s pomočjo zdravilnih svojstev zelišč. Zagreb: D. Beker; 1933

12. Mihelčič $F$. Naše zdravilne rastline : o njih nabiranju, sušenju, pripravi in uporabi. Celovec: Družba sv. Mohorja; 1956

13. Kromar J. Naše domače zdravilne rastline. Celje: Mohorjeva družba; 1958

14. Mességué M. Narava ima vselej prav [C'est la nature qui a raison]. Ljubljana: Cankarjeva založba; 1974

15. Kromar J, Palko G, Gracej H, Gracej B. Zdravilne rastline : 1000 izbranih receptov. Murska Sobota: Pomurska založba; 1975

16. Neuthaler H. Zdravilna zelišča [Das Kräuterbuch]. Trst: Založništvo tržaškega tiska; 1977

17. Weiss RF. Sodobno zdravljenje z rastlinami [Moderne Pflanzenheilkunde]. Ljubljana: Državna založba Slovenije; 1977

18. Wilfort R. Zdravilne rastline in njih uporaba, 2nd edn. Maribor: Obzorja; 1978

19. Bohinc P, Svolinský K, Hísek K, Testen J, Pintar L. Slovenske zdravilne rastline : vodnik za nabiranje in pripravo zdravilnih zelišc. Ljubljana: Mladinska knjiga; 1979

20. Vidmajer J, Soldatović M, Željeznov D. Zelišča, čaji in kozmetika. Ljubljana: Cankarjeva založba; 1980

21. Ašič S. Pomoč iz domače lekarne : ob 850-letnici stiškega samostana (1135-1985). Celje: Mohorjeva družba; 1984

22. Vogel A. Ljudski zdravnik [Der kleine Doktor]. Ljubljana: Mladinska knjiga; 1985

23. Ašič S. Pomoč iz domače lekarne II. Celje: Mohorjeva družba; 1987

24. Ašič S. Priročnik za nabiranje zdravilnih rastlin. Celje: Mohorjeva družba; 1989.

25. Treben M. Zdravje iz Božje lekarne : nasveti in izkušnje z zdravilnimi zelišči. Celje: Mavrica; 1992

26. Bremness L. Velika knjiga o zeliščih [The complete book of herbs]. Ljubljana: Mladinska knjiga; 1996

27. Toplak Galle K, Pintar L, Sedmak A. Zdravilne rastline na Slovenskem. Ljubljana: Mladinska knjiga; 2000

28. Brancelj R. Kras. In: Perko D, Orožen Adamič M, editors. Slovenia. 2nd ed. Ljubljana: Mladinska knjiga; 1999. p. 234-245

29. Lokar LC, Poldini L. Herbal remedies in the traditional medicine of the Venezia Giulia region (north east Italy). J Ethnopharmacol. 1988;22:231-79.

30. Guštin Grilanc V. Beri, beri rožmarin zeleni: kraška zelišča v ljudski. Trieste: Transalpina; 2005

31. Perko D. Gorjanc. In: Perko D, Orožen Adamič M, editors. Slovenia. 2nd ed. Ljubljana: Mladinska knjiga; 1999. p. 498-507

32. Makarovič MO. ljudskem zdravilstvu iz Dolenjskega in iz Bele Krajine; 2001. Traditiones. 2001;2:89-112 
33. Razinger Mihovec B. Vpliv socialno-demografskih značilnosti in zdravstvenega stanja populacije na uporabo zdravil rastlinskega izvora $\checkmark$ Sloveniji [The influence of socio-demographic characteristics and health status of the population on the use of herbal medicines in Slovenia]. Master Thesis. Ljubljana: Faculty of Pharmacy, University of Ljubljana; 2007

34. Kralj M. Ovredontenje uporabe in odnosa uporabnikov do zdravilnih rastlin in njihovih pripravkov pri samozdravljenju [Evaluation of use and attitude towards herbs and herbal medicines in self-medication]. Graduation Thesis. Ljubljana: Faculty of Pharmacy, University of Ljubljana; 2001

35. Klemenc-Ketiš Z, Verovnik F. Uporaba zdravilnih rastlin Med prebivalci Velenja [the use of the medicinal herbs in the city of Velenje]. Zdrav Vestn. 2004;73:59-62.

36. Papež A. Uporaba divje rastočih rastlin $\vee$ prehrani [Use of wild-growing edible plants in human nutrition]. Graduation Thesis. Ljubljana: Biotechnical Faculty, University of Ljubljana; 2010

37. Grasser S, Schunko C, Vogl CR. Gathering "tea" - from necessity to connectedness with nature. Local knowledge about wild plant gathering in the biosphere reserve grosses Walsertal (Austria). J Ethnobiol Ethnomed. 2012;8:31.

38. Schunko C, Grasser S, Vogl CR. Explaining the resurgent popularity of the wild: motivations for wild plant gathering in the biosphere reserve grosses Walsertal, Austria. J Ethnobiol Ethnomed. 2015;11:55.

39. Bellia G, Pieroni A. Isolated, but transnational: the glocal nature of Waldensian ethnobotany, Western Alps, NW Italy. J Ethnobiol Ethnomed. 2015;11:37.

40. Signorini MA, Piredda M, Bruschi P. Plants and traditional knowledge: an ethnobotanical investigation on Monte Ortobene (Nuoro, Sardinia). J Ethnobiol Ethnomed. 2009;5:6.

41. Di Sanzo P, De Martino L, Mancini E, Feo VD. Medicinal and useful plants in the tradition of Rotonda, Pollino National Park, Southern Italy. J Ethnobiol Ethnomed. 2013;9:19.

42. Menale B, De Castro O, Cascone C, Muoio R. Ethnobotanical investigation on medicinal plants in the Vesuvio National Park (Campania, Southern Italy). J Ethnopharmacol. 2016;192:320-49.

43. Petrič $M$, In Kranjc KH, A, Likar V, Žalik Huzjan M, editors. Kras: pokrajina, življenje, ljudje. Ljubljana: ZRC SAZU; 1999. p. 55-63.

44. Zupančič M. Gozdna in grmiščna vegetacija krasa. In: Kranjc A, Likar V, Žalik Huzjan M, editors. Kras: pokrajina, življenje, ljudje. Ljubljana: ZRC SAZU; 1999. p. 55-63

45. Kladnik D. Družbenogospodarska sestava prebivalstva in dnevna mobilnost. In: Luthar O, Dobrovoljc H, Fridl J, Mulec J, Pavšek M, editors. Kras. Trajnostni razvoj kraške pokrajine. Ljubljana: ZRC SAZU; 2008. p. 214-23

46. Tongco MDC. Purposive sampling as a tool for informant selection. Ethnobot Res Appl. 2007:5:147-58.

47. Bernard HR. Research methods in anthropology: qualitative and quantitative methods. 4th ed. Oxford: AltaMira Press; 2007.

48. Borgatti SP. Cultural domain analysis. J Quant Anthropol. 1994;4:261-78.

49. Microsoft. Microsoft Excel 2010. Redmont: Microsoft Press Corporation; 2010

50. Anthropac V. Software for cultural domain analysis: freelists. Analytic Technologies; 2003

51. IBM Corp. IBM SPSS statistics for Windows, version 23. Armonk: IBM Corporation; 2015.

52. Smith JJ. Using ANTHROPAC 3.5 and a spreadsheet to compute a free list salience index. Cultural Anthropology Methods. 1993;5:1-3.

53. Martinčič A, Wraber T, Jogan N, Ravnik V, Podobnik A, Turk B, et al. Mala flora Slovenije: ključ za določanje praprotnic in semenk. Ljubljana: Tehniška založba Slovenije; 1999

54. Christanell A, Vogl-Lukasser B, Vogl CR, Gütler M. The cultural significance of wildgathered plant species in Kartitsch (Eastern Tyrol, Austria) and the influence of socioeconomic changes on local gathering practices. In: Pardo-de-Santayana M, Pieroni A, Puri RK, editors. Ethnobotany in the new Europe: people, health and wild plant resources. New York: Berghahn Books; 2010. p. 51-75.

55. Ghirardini MP, Carli M, del Vecchio N, Rovati A, Cova O, Valigi F, et al. The importance of a taste. A comparative study on wild food plant consumption in twenty-one local communities in Italy. J Ethnobiol Ethnomed. 2007;3:22

56. Pirker H, Haselmair R, Kuhn E, Schunko C, Vogl CR. Transformation of traditional knowledge of medicinal plants: the case of Tyroleans (Austria) who migrated to Australia, Brazil and Peru. J Ethnobiol Ethnomed. 2012:8:44.
57. Hazler Pilepić K, Antolković A, Maleš Ž, Crkvenčić M. Etnobotaničko istraživanje o uporabi biljaka u ljekovite svrhe na području Svetog Ivana Zeline (An ethnobotanical survey on the use of plants for medicinal purposes in the area of Sveti Ivan Zelina). Farm Glas. 2015;71:459-66.

58. Vitasović Kosić I, Juračak J. Etnobotaničko istraživanje na Ćićariji (Istra, Hrvatska): Korištenje samoniklog bilja i gljiva. In: Rešetnik I, Ljubešić Z, editors. 5th Croatian Botanical Symposium with international participation book of abstracts. Zagreb: Croatian Botanical Society; 2016. p. 32-3.

59. Sarić-Kundalić B, Dobeš C, Klatte-Asselmeyer V, Saukel J. Ethnobotanical survey of traditionally used plants in human therapy of east, north and north-east Bosnia and Herzegovina. J Ethnopharmacol. 2011;133:1051-76.

60. Pardo-de-Santayana M, Quave CL, Sõukand R, Pieroni A. Medical ethnobotany and ethnopharmacology of Europe. In: Heinrich M, Jäger AK, editors. Ethnopharmacol. Wiley-Blackwell; 2015. p. 343-56.

61. Schunko C, Vogl CR. Organic farmers use of wild food plants and fungi in a hilly area in Styria (Austria). J Ethnobiol Ethnomed. 2010;6:17.

62. Šavikin K, Zdunić G, Menković N, Živković J, Ćujić N, Tereščenko M, et al. Ethnobotanical study on traditional use of medicinal plants in SouthWestern Serbia, Zlatibor District. J Ethnopharmacol. 2013;146:803-10.

63. Zlatković BK, Bogosavljević SS, Radivojević AR, Pavlović MA. Traditional use of the native medicinal plant resource of Mt. Rtanj (Eastern Serbia): ethnobotanical evaluation and comparison. J Ethnopharmacol. 2014;151:704-13.

64. Jarić S, Mačukanović-Jocić M, Djurdjević L, Mitrović M, Kostić O, Karadžić B, et al. An ethnobotanical survey of traditionally used plants on Suva planina mountain (south-eastern Serbia). J Ethnopharmacol. 2015;175:93-108.

65. Jarić S, Popović Z, Macukanović-Jocić M, Djurdjević L, Mijatović M, Karadzić $B$, et al. An ethnobotanical study on the usage of wild medicinal herbs from Kopaonik Mountain (Central Serbia). J Ethnopharmacol. 2007;111:160-75.

66. Šarić-Kundalić B, Dobes C, Klatte-Asselmeyer V, Saukel J. Ethnobotanical study on medicinal use of wild and cultivated plants in middle, south and west Bosnia and Herzegovina. J Ethnopharmacol. 2010;131:33-55.

67. Jogan N, Bačič T, Frajman B, Leskovar I, Naglič D, Podobnik A, et al. Materials for the atlas of flora of Slovenia. Miklavž na Dravskem Polju: Center Za kartografijo favne in Flore; 2001.

68. Mezinec P. Na Krasu bo zadišalo po sivki. Primorske novice. 2015. http://www.primorske.si/Plus/Sobota/Na-Krasu-bo-zadisalo-po-sivki. Accessed 15 Dec 2016

69. Kujawska M, Łuczaj Ł, Typek J. Fischer's lexicon of Slavic beliefs and customs: a previously unknown contribution to the ethnobotany of Ukraine and Poland. J Ethnobiol Ethnomed. 2015;11:85.

70. Ferrier J, Saciragic L, Trakić S, Chen EC, Gendron RL, Cuerrier A, et al. An ethnobotany of the Lukomir highlanders of Bosnia \& Herzegovina. J Ethnobiol Ethnomed. 2015;11:81.

71. Pieroni A, Giusti ME, Münz H, Lenzarini C, Turković G, Turković A. Ethnobotanical knowledge of the Istro-Romanians of Zejane in Croatia. Fitoterapia. 2003:74:710-9.

72. Pieroni A, Giusti ME. The remedies of the folk medicine of the Croatians living in Cićarija, northern Istria. Coll Antropol. 2008;32:623-7.

73. Guarrera PM. Traditional phytotherapy in Central Italy (Marche, Abruzzo, and Latium). Fitoterapia. 2005:76:1-25.

74. Dei Cas L, Pugni F, Fico G. Tradition of use on medicinal species in Valfurva (Sondrio, Italy). J Ethnopharmacol. 2015;163:113-34.

75. Etkin NL, Ross PJ. Food as medicine and medicine as food. An adaptive framework for the interpretation of plant utilization among the Hausa of northern Nigeria. Soc Sci Med. 1982;16:1559-73.

76. Scherrer AM, Motti R, Weckerle CS. Traditional plant use in the areas of Monte Vesole and Ascea, Cilento National Park (Campania, Southern Italy). J Ethnopharmacol. 2005;97:129-43.

77. Sõukand R, Kalle R. Where does the border lie: locally grown plants used for making tea for recreation and/or healing, 1970s-1990s Estonia. J Ethnopharmacol. 2013;150:162-74.

78. Jennings HM, Merrell J, Thompson JL, Heinrich M. Food or medicine? The food-medicine interface in households in Sylhet. J Ethnopharmacol. 2015;167:97-104.

79. Wildman REC, Kelley M. Nutraceuticals and functional foods. In: Wildman REC, editor. Handbook of nutraceuticals and functional foods. 2nd ed. Boca Raton: CRC press; 2007. p. 1-21.

80. Judgment of the Court (First Chamber) in Case C-319/05, Commission of the European Communities v Federal Republic of Germany. 15 November 2007. http://curia.europa.eu/juris/liste.jsf?num=C-319/05. Accessed 15 Dec 2016. 
81. Pieroni A, Howard P, Volpato G, Santoro RF. Natural remedies and nutraceuticals used in ethnoveterinary practices in inland southern Italy. Vet Res Commun. 2004;28:55-80.

82. Disler M, Ivemeyer $\mathrm{S}$, Hamburger $\mathrm{M}$, Vogl CR, Tesic A, Klarer F, et al. Ethnoveterinary herbal remedies used by farmers in four north-eastern Swiss cantons (St. Gallen, Thurgau, Appenzell Innerrhoden and Appenzell Ausserrhoden). J Ethnobiol Ethnomed. 2014;10:32.

83. Mayer M, Vogl CR, Amorena M, Hamburger M, Walkenhorst M. Treatment of organic livestock with medicinal plants: a systematic review of European ethnoveterinary research. Forsch Komplementmed. 2014;21:375-86.

84. Vogl CR, Vogl-Lukasser B, Walkenhorst M. Local knowledge held by farmers in Eastern Tyrol (Austria) about the use of plants to maintain and improve animal health and welfare. J Ethnobiol Ethnomed. 2016;12:40.

85. Ministrstvo za kmetijstvo, gozdarstvo in prehrano. Tehnična dokumentacija brinjevca. http://www.mkgp.gov.si/fileadmin/mkgp.gov.si/pageuploads/ podrocja/Kmetijstvo/Kakovost/zgane_pijace/tehnicna_dokumentacija_ brinjevec.pdf. Accessed 12 July 2016.

86. Cavalli-Sforza LL, Feldman MW, Chen KH, Dornbusch SM. Theory and observation in cultural Transmission. Science. 1982;218:19-27.

87. Hewlett BS, Cavalli-Sforza LL. Cultural transmission among Aka pygmies. Am Anthropol. 1986;88:922-34.

88. Leonti M. The future is written: impact of scripts on the cognition, selection knowledge and transmission of medicinal plant use and its implications for ethnobotany and ethnopharmacology. J Ethnopharmacol. 2011;134:542-55.

89. Haselmair R, Pirker H, Kuhn E, Vogl CR. Personal networks: a tool for gaining insight into the transmission of knowledge about food and medicinal plants among Tyrolean (Austrian) migrants in Australia, Brazil and Peru. J Ethnobiol Ethnomed. 2014;10:1.

90. Köhler P. An Involuntary Ethnobotanist? In: Svanberg I, and Łuczaj Ł, editors. Pioneers in European Ethnobiology. Uppsala: Uppsala University; 2014. p. 149-180.

\section{Submit your next manuscript to BioMed Central and we will help you at every step:}

- We accept pre-submission inquiries

- Our selector tool helps you to find the most relevant journal

- We provide round the clock customer support

- Convenient online submission

- Thorough peer review

- Inclusion in PubMed and all major indexing services

- Maximum visibility for your research

Submit your manuscript at www.biomedcentral.com/submit 